\title{
New Muricidae (Neogastropoda) faunas from the Middle Miocene of Hungary
}

\author{
KovÁCs, Zoltán
}

Hungary, Budapest, Kerékgyártó utca 27/A

https://www.researchgate.net/profile/Zoltan_Kovacs4

E-mail: kzkovacszoltan@gmail.com,

Összefoglalás

\section{Új, magyarországi középsó-miocén Muricidae (Neogastropoda) faunák}

\begin{abstract}
Jelen tanulmány a badeni (kora-középső-miocén) Középső-Paratethys gastropoda-diverzitásának pontosabb ismeretéhez járul hozzá hét Muricidae-összlet bemutatásával. A több mint 50 fajt tartalmazó anyag a badeni Pannóniaimedence északi és nyugati részéből, a Börzsöny, a Bakony és a Mecsek hegységből származik. Bánd kora-badeni faunája különleges figyelemre tarthat igényt egy faj, a Janssenia echinulata (PUSCH) szokatlan gyakorisága miatt. Mecsekpölöskén a Favartia suboblonga (D’ORBIGNY), míg Hidas térségében egy középső-badeni feltárás faunájában az Ocinebrina confluens (EICHWALD) faj jelenik meg más lelőhelyekhez képest tömeges előfordulásban. Néhány ritka species szélesebb ősföldrajzi elterjedése mellett nyolc faj: Bolinus brandaris torularius (LAMARCK), Dermomurex scalaroides (BLAINVILLE), Pterynotus pseuderinaceus (BOETTGER), Ocinebrina landaui Kovács, Pteropurpura friedbergi (Cossmann \& PeYROT), Phyllocoma michelottii (Bellardi), Coralliophila sacyi (Cossmann \& PeYrot), C. serraticincta Batuk, valamint egy trophonine nemzetség, a Pterynopsis új magyarországi előfordulása dokumentálható a vizsgált anyag alapján. Egy új faj, Ocinebrina bertai $\mathrm{n}$. sp. is bevezetésre kerül a bándi középső-miocén lelőhelyről.
\end{abstract}

Tárgyszavak: miocén, badeni, Muricidae, Középsó-Paratethys, Pannóniai-medence

\begin{abstract}
The aim of this paper is to contribute to a better understanding of the actual diversity of the Early - Middle Badenian (Langhian; middle Miocene) gastropods from the Central Paratethys. This will be attempted by presenting seven Muricidae assemblages including more than 50 species from the northern and western part of the Pannonian Basin System (Börzsöny, Bakony and Mecsek Mts, Hungary). The Early Badenian fauna of Bánd (Bakony Mts) is of special interest due to its marked abundance of Janssenia echinulata (PUSCH); the fauna of Mecsekpölöske (Mecsek Mts) is characterised by the unusual dominance of Favartia suboblonga (D'ORBIGNY), while the Middle Badenian fauna from Locality 2 at Hidas (Mecsek Mts) includes a mass occurrence of Ocinebrina confluens (EICHWALD). Extended geographical range of some rare species is also documented. Furthermore, eight species: Bolinus brandaris torularius (LAmarck), Pterynotus pseuderinaceus (BoettGer), Dermomurex scalaroides (BlainVILle), Ocinebrina landaui Kovács, Pteropurpura friedbergi (COSSMAnn \& PeYrot), Phyllocoma michelottii (Bellardi), Coralliophila sacyi (Cossmann \& PEYRot), C. serraticincta BAŁUK, and a trophonine genus: Pterynopsis are recorded as new in Hungary. A new species, Ocinebrina bertai $\mathrm{n}$. sp. is also designated from the Middle Miocene locality of Bánd.
\end{abstract}

Keywords: Miocene, Badenian, Muricidae, Central Paratethys, Pannonian Basin System

\section{Introduction}

The aim of this paper is to examine the actual gastropod diversity and palaeogeographical distribution in the Middle Miocene Pannonian Basin by revision of the family Muricidae. Previous papers (Kovács 2018a, KovÁcs et al. 2018) have already described the highly diverse muricid assemblage of Letkés (W Börzsöny Mts, N Hungary). Now beside a new record from Letkés - the muricid materials of W Hungary are presented from newly collected mollusc assemblages in the Bakony Mts (Bánd), and in the Mecsek Mts (Mecsekpölöske, Kisbattyán, Hosszúhetény, Hidas, 


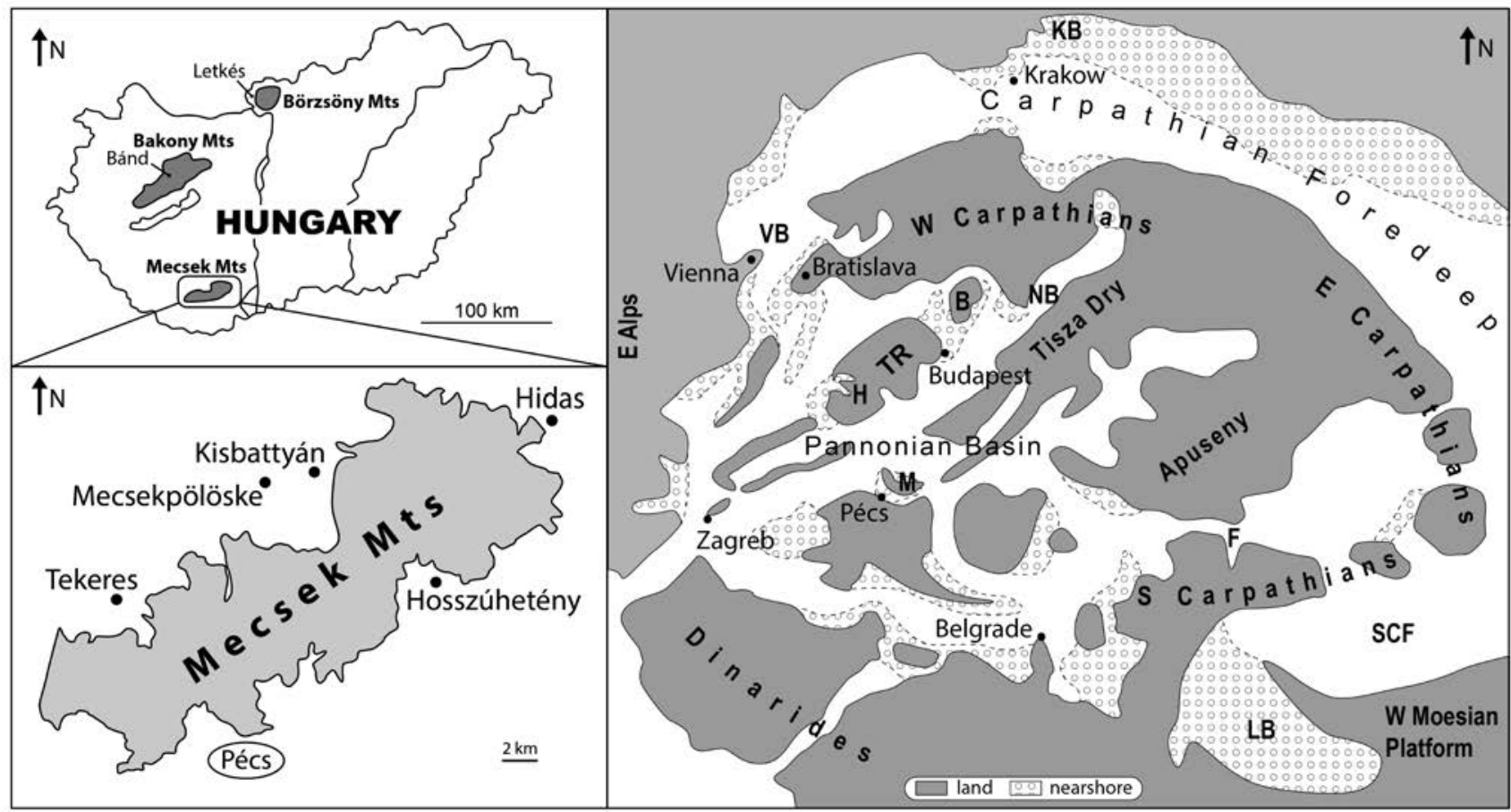

Figure 1. Early Badenian fossiliferous sites mentioned in the text, and their locations in the Central Paratethys. (B - Börzsöny Mts, F - Făget Basin, H - Herend Basin, KB - Korytnica Basin, LB - Lom Basin, M - Mecsek Mts, NB - Nógrád Basin, TR - Transdanubian Range, SCF - South Carpathian Foredeep, VB Vienna Basin) (modified from HAAs 2012 and SANT et al. 2019)

1. ábra. A szövegben emlitett középsö-miocén ősmaradvány-lelöhelyek, és ösföldrajzi helyzetük a kora-badeni Középsö-Paratethys területén

and Tekeres) (Figure 1). Thus new data are offered for the geographical range and diversity of the family in the Middle Miocene Central Paratethys. The outstanding richness of certain gastropod groups (e.g. Buccinidae, Cypraeidea, Tonnoidea, Ficoidea, Conoidea and Siphonarioidea) in the region was the result of the immigration of thermophilic molluscs from the Mediterranean during the Mid-Miocene Climate Optimum (HARZHAUSER et al. 2003).

The Early Badenian locality of Letkés (Börzsöny Mts) was thoroughly discussed by KovÁcs \& ViCIÁN (2014, 2018). Deposits of the Lower Badenian Pécsszabolcs Formation are rich in molluscs, and gastropods were described by CSEPREGHY-MEZNERICS (1956), HARZHAUSER \& LANDAU (2016), HARZHAUSER et al. (2017) and ViCIÁN et al. (2017).

The geological background of the small Herend Basin was dealt with by KóKAY (1966, 2006), and DUDKO et al. (1992). During the Early Badenian transgression, the sea formed a narrow embayment in the mountains; the Lower Badenian succession consists of paludal-lacustrine to shallow marine sediments of approx. $300 \mathrm{~m}$ thickness. Fossiliferous localities near Bánd and Herend have yielded rich Badenian invertebrate assemblages; marine molluscs were described by KÓKAY (1966), STRAUSZ (1966), FEHSE \& ViCián (2004), DUlai (2005), ViCIÁN et al. (2017) and KovÁCs (2018b).

The Mecsek Mts is an isolated mountainous range in SW Hungary built up of different Permian and Mesozoic rocks, during the Miocene this range was an island surrounded by a largely shallow sea. Over the last 150 years the geological and stratigraphical properties of the area have been studied in numerous papers (BÁLDI et al. 2002). The diverse lagoonal, coastal and nearshore Badenian facies (Budafa Sandstone, Hidas Brown Coal, Lajta Limestone and Tekeres Schlier formations) were recently discussed by SEBE et al. (2015) and SELMECZI (2015). The Lower Badenian deposits investigated herein represent the lower part of the Lajta Limestone Formation, locally referred to as "Pécsszabolcs Limestone". It is "a mixture of basal breccias and conglomerates, glauconitic sand(stone)s, bioclastic limestones and mollusc-, echinoidea- and bryozoa-bearing calcareous sands and silts" of 30-50 m thickness (SEBE et al. 2015), it was deposited in the nearshore to littoral zones. The Middle Badenian Hidas Brown Coal Formation represents a brackish-water brown coal, mollusc-bearing marl of 100 $150 \mathrm{~m}$ thickness and it "comprises clayey, xylithic brown coal seam-bearing rocks (lignite, clayey lignite, huminitic clay) which are situated between the underlying and overlying marine formations" (SELMECZI 2015). The gastropod faunas of this region are poorly known and there are only two monographs which contain detailed analyses of Badenian molluscs: CSEPREGHY-MEZNERICS (1950) dealt with the Hidas area, while BoHN-HAVAS (1973) investigated mainly assemblages from drill cores. With the exception of Tekeres, the localities described herein in the Mecsek Mts have so far not been discussed in the literature. A comprehensive investigation of the newly collected gastropods in the studied assemblages is still in progress, only the muricid species are documented in the present paper. 


\section{Materials and methods}

The specimens investigated herein are stored in the collections of (i) the Mining and Geological Survey of Hungary (MGSH), (ii) the Hungarian Natural History Museum (HNHM), Budapest, and (iii) in the private collections of Tibor BERTA (Veszprém), László NÁDAI (Budapest), Tamás NÉMETH (Balatonkenese), László Sövér (Bonyhád) and Zoltán VICIÁN (Budapest) (Hungary). The Muricidae taxonomy is discussed in the recent literature; the suprageneric classification given in this paper provisionally follows MERLE et al. (2011), LANDAU et al. (2007, 2013) and HOUART (2018). The comprehensive works of BAŁUK (1995, 2006), HARZHAUSER (2002), Kovács et al. (2018) and KovÁcs (2019) were also used for taxonomical revision. 21 taxa of special interest are described systematically. The figured specimens belong to private collections except Figure 2 (see later) and Plate I/29. Abbreviation: shell length (SL) in mm.

\section{Localities and faunas}

\section{Börzsöny Mts: Letkés}

The locality is situated about $400 \mathrm{~m}$ to the east of Letkés village $\left(47.888319^{\circ} \mathrm{N}, 18.784647^{\circ} \mathrm{E}\right)$. The deposits - resedimented beds of limonitic marly sand with andesite rock fragments, andesitic tuff and eroded colonial coral blocks represent the Lower Badenian Pécsszabolcs Formation that was deposited in littoral-sublittoral zones. The macrofauna shows a mixture of taxa deriving from different biotopes. The Muricidae was described in detail by KovÁcs (2018a) and KovÁcs et al. (2018), this material is completed herein with a newly collected specimen from the private collection of VICIÁN that represents a new record in the Paratethys: Phyllocoma michelottii. The muricid assemblage of Letkés with 54 species is one of the richest in the Paratethys.

\section{Bakony Mts, Herend Basin: Bánd}

The materials studied herein were collected from Locality 28 (KÓKAY 1966), $250 \mathrm{~m}$ south-east of the village church of Bánd $\left(47.121087^{\circ} \mathrm{N}, 17.786770^{\circ} \mathrm{E}\right)$ in artificial trenches. The deposits - mollusc- and coral-bearing grey clay and clayey sand of approx. $2 \mathrm{~m}$ thickness with thin fine-grained yellow sand layers - represent the Lower Badenian Pécsszabolcs Formation. The colonial coral remains - as well as the rich brachiopod, polyplacophoran, gastropod and bivalve materials - indicate intertidal to sublittoral zones, and a patch reef environment (DULAI 2007).

Four collections were examined: 1. The assemblage containing ten muricids described by KÓKAY (1966) from "Excavation 28" (stored in the MGSH); 2. A large material collected by KóKAY in 1984 from the same excavation (HNHM); 3. The material listed by BERTA \& NÉMETH (2004); 4. The gastropod assemblage of more than 10,000 specimens — including approx. 7000 muricid specimens - collected by NÉMETH in 2017. Based on this large volume of materials, it was possible to identify 38 species (Table I).

The most significant feature of the assemblage is the extreme abundance of the ergalataxine Janssenia echinulata (more than 5600 specimens). The appearance of other rare ergalataxines - J. spinosa and Morula (Habromorula) austriaca - and the frequent occurrence of $M$. bellardii are also remarkable. The most abundant examples in the subfamily Muricinae are Hexaplex (Trunculariopsis) austriacus (= Murex gavardanensis in KÓKAY 1966), Chicoreus (Triplex) borni, and Homalocantha heptagonata. In the Aspellinae one rare species occurs: Aspella emmae. The dominance of Muricopsis cristata in the Muricopsinae is common in Middle Miocene Paratethyan localities, however, the respective occurrences of Murexsul typhioides, Favartia absona and F. czjzeki, as well as the abundance of F. (Pygmaepterys) transsylvanica can be considered remarkable. In the Ocenebrinae the abundance of Ocinebrina kojumdgievae and Vitularia linguabovis is also significant. Two specimens of the extremely rare Ceratostoma subaustriacus were found. A new species, Ocinebrina bertai n. sp. has also been designated from the locality (see later Figure 2). The Typhinae and Coralliophilinae are underrepresented. One specimen of Typhinellus labiatus (Plate $I / 29$, collected by KóKAY in 1984), and one specimen of Tripterotyphis tripterus are all that represent the subfamily Typhinae. (The latter has been recorded only at Letkés in Hungary.) Although colonial corals and vermetids are common in the assemblage, only three coralliophilines Coralliophila burdigalensis, C. sacyi and Leptoconchus jaegeri - occur sporadically. Muricodrupa? styriaca was recorded by KóKAY (1966) at Bánd but is missing from the newly collected material.

\section{Mecsek Mts: Mecsekpölöske}

The geology and stratigraphy of the Mecsekpölöske region were examined earlier by STRAUSZ (1928), and CHIKÁN (1991). The Lower Badenian deposits represent the Pécsszabolcs Limestone. Muricids have not been recorded in this region. The newly discovered locality is located $1 \mathrm{~km}$ east of the village, in a ravine on the western side of the Nagy Hill $\left(46.22311^{\circ} \mathrm{N}, 18.22904^{\circ} \mathrm{E}\right)$. Three collections were examined: the mollusc assemblage collected by the staff of the HNHM and the respective private collections of NÉMETH and SövÉR.

Alternating layers of mollusc-bearing limestone and dark yellow sandy clay of approx. $3 \mathrm{~m}$ thickness were excavated in the locality. The mollusc shells in the clay are very well-preserved, while the limestone benches contain poorly preserved internal molds. In the Muricidae the abundance of Purpurellus cyclopterus, Aspella subanceps, Murexsul sandbergeri and Favartia suboblonga, as well as the appearance of rare species such as Pterynotus pseuderinaceus, $F$. absona, Coralliophila gracilispira and $C$. serraticincta are noteworthy. The Muricidae species of the locality are shown on Table I. The muricid faunal com- 
Table I. Muricidae species of the investigated Early Badenian assemblages.

I. táblázat. Muricidae-fajok a vizsgált kora-badeni összletekben. E-Középső-Paratethysre jellemzö endemikus faj

\begin{tabular}{|c|c|c|c|c|c|c|c|c|}
\hline Subfamily Muricinae & $E$ & Illustration & B & M & $\mathrm{K}$ & $\mathrm{H}$ & $\mathrm{Hh}$ & $\mathrm{T}$ \\
\hline Bolinus brandaris torularius (LAMARCK, 1822) & & Plate $\mathrm{V} / 1-3$ & & & & 12 & 1 & \\
\hline Bolinus submuticus (GRATELOUP, 1845) & & Plate $\mathrm{I} / 4-5$ & 2 & & & & & 1 \\
\hline Bolinus subtorularius (HOERNES \& AUINGER, 1885) & $\mathrm{x}$ & KÓKAY I.c., pl. 7/18-19 & 12 & & 1 & & & \\
\hline Hexaplex (Trunculariopsis) austriacus (TouRnouëR, 1875) & & Plate $1 / 6-9$ & 211 & & 2 & 23 & 2 & \\
\hline Chicoreus (Triplex) aquitanicus (GRATELOUP, 1833) & & Plate $\mathrm{V} / 10$ & & & 1 & & 17 & \\
\hline Chicoreus (Triplex) borni (HÖRNES, 1853) & $\mathrm{x}$ & Plates $\mathrm{l} / 11-14$ & 126 & 2 & & & 26 & \\
\hline Purpurellus cyclopterus (MILLET, 1865) & & Plate $\mathrm{V} / 15-16$ & 16 & 54 & 9 & & & \\
\hline \multicolumn{9}{|l|}{ Subfamily Aspellinae } \\
\hline Aspella emmae (BoETTGER, 1902) & & Plate $\mathrm{V} / 17-18$ & 4 & & & & & \\
\hline Aspella subanceps (D'ORBIGNY, 1852) & & Plate I/19-20 & & 56 & & & & \\
\hline Dermomurex (D.) distinctus (CRISTOFORI \& JAN, 1832) & & Plate $1 / 21-22$ & 3 & & & & & \\
\hline Dermomurex (D.) scalaroides (BLAINVILLE, 1826) & & Plate $1 / 23-24$ & & 2 & 1 & & & 1 \\
\hline Dermomurex (Trialatella) jani (DODERLEIN, 1862) & & & 1 & & & & & \\
\hline Dermomurex (Dermomurex) sp. & & Plate $1 / 25-26$ & & 1 & & & & \\
\hline \multicolumn{9}{|l|}{ Uncertain subfamily } \\
\hline Homalocantha heptagonata (BRONN, 1831) & & & 24 & & & & & \\
\hline Pterynotus (P.) pseuderinaceus (BOETTGER, 1902) & $\mathrm{x}$ & Plate 1/27-28 & & 1 & & & & \\
\hline \multicolumn{9}{|l|}{ Subfamily Typhinae } \\
\hline Typhis (Hirtotyphis) horridus (BROCCHI, 1814) & & & & & & & & 1 \\
\hline Typhinellus labiatus (CRISTOFORI \& JAN, 1832) & & Plates I/29, II/1-2 & 1 & 2 & & 15 & & \\
\hline Siphonochelus fistulosus (BROCCHI, 1814) & & Plate II/3-4 & & & & & & 31 \\
\hline Tripterotyphis tripterus (GRATELOUP, 1833) & & Plate II/5-6 & 1 & & & & & \\
\hline \multicolumn{9}{|l|}{ Subfamily Muricopsinae } \\
\hline Muricopsis (Muricopsis) cristata (BROCCHI, 1814) & & KÓKAY I.C., pl. 7/20 & 317 & 76 & & & & \\
\hline Subpterynotus graniferus (MicHELOTTI, 1841) & & Plate II/7-8 & 1 & & & & & \\
\hline Murexsul sandbergeri (HöRNES, 1856) & & Plate II/9-11 & & 56 & & & & \\
\hline Murexsul typhioides (MAYER, 1869) & & Plate II/12-13 & 2 & & & & & \\
\hline Favartia (F.) absona (CRISTOFORI \& JAN, 1832) & & Plate II/14-15 & 5 & 2 & & & & \\
\hline F. (F.) czjzeki (HOERNES \& AUINGER, 1885) & & Plate II/16-17 & 1 & & & & & \\
\hline F. (F.) suboblonga (D’ORBIGNY, 1852) & & Plate II/18-19 & & 228 & 4 & & & \\
\hline F. (Pygmaepterys) transsylvanica (HoERnES \& AUINGER, 1885) & $\mathrm{x}$ & Plate II/20-21 & 43 & & & & & \\
\hline \multicolumn{9}{|l|}{ Subfamily Ocenebrinae } \\
\hline Ocinebrina boeckhi (HOERNES \& AUINGER, 1885) & $x$ & Plate II/22-23 & & & 1 & & & \\
\hline Ocinebrina credneri (HOERNES \& AUINGER, 1885) & $\mathrm{x}$ & & 96 & & & & & \\
\hline Ocinebrina dertonensis (BELLARDI, 1873) & & Plate II/26 & 3 & & & & 61 & \\
\hline Ocinebrina grundensis (HOERNES \& AUINGER, 1885) & $\mathrm{X}$ & KÓKAY I.c., pl. 8/2 & 1 & & & & & \\
\hline Ocinebrina kojumdgievae (BA UK, 1995) & $x$ & Plate II/27-30 & 162 & & & & & \\
\hline Ocinebrina landaui KovÁCS, 2019 & & Plate III/1-2 & 5 & & & & & \\
\hline Ocinebrina bertai $\mathrm{n} . \mathrm{sp}$. & $x$ & Figure 2. & 3 & & & & & \\
\hline Ocinebrina sp. & & Plate III/3-4 & 3 & & & & & \\
\hline Ocenebra vindobonensis (HÖRNES, 1853) & & Plate III/5-7 & & & & & 740 & \\
\hline Hadriania mioincrassata $(\mathrm{SACCO}, 1904)$ & & Plate III/8-9 & 7 & & & 88 & & \\
\hline Jaton sowerbyi (MICHELOTTI, 1841) & & Plate III/10-14 & 80 & & & & 15 & \\
\hline Pteropurpura friedbergi (COSSMANN \& PEYROT, 1924) & & Plate III/15-16 & & & & & & 36 \\
\hline Ceratostoma subaustriacus (STOJASPAL, 1978) & $\mathrm{x}$ & Plate III/17-18 & 2 & & & & & \\
\hline Vitularia linguabovis (BASTEROT, 1825) & & Plate III/19-20 & 132 & & & 2 & 190 & \\
\hline \multicolumn{9}{|l|}{ Subfamily Trophoninae } \\
\hline Pterynopsis sp. & & Plate IV/1-2 & & & 1 & & & \\
\hline \multicolumn{9}{|l|}{ Subfamily Ergalataxinae } \\
\hline Orania cheilotoma (HOERnES \& AUINGER, 1890) & & & 14 & & & & & \\
\hline Janssenia echinulata (PuSCH, 1837) & & Plate IV/3-10 & 5.600 & 3 & & 3 & 31 & \\
\hline Janssenia spinosa (KoJumDGIEVA, 1960) & $x$ & Plate IV/11-12 & 93 & & & & & \\
\hline Cathymorula exilis (HÖRNES, 1852) & & Plate IV/13-14 & 25 & & & 4 & 11 & \\
\hline
\end{tabular}


Table I. Continuation

I. táblázat. Folytatás

\begin{tabular}{|l|c|c|c|c|c|c|c|c|}
\hline Subfamily Ergalataxinae & E & Illustration & B & M & K & H & Hh & T \\
\hline Morula (M.) bellardii (HOERNES \& AUINGER, 1890) & & Plate IV/15-16 & 51 & & & & & \\
\hline M. (Habromorula) austriaca (HOERNES \& AUINGER, 1882) & $\mathrm{x}$ & Plate IV/17-18 & 8 & & & & \\
\hline Muricodrupa? styriaca (Hilber, 1879) & $\mathrm{x}$ & KóKAY I.c. pl. 8/1 & 2 & & & & & \\
\hline Subfamily Coralliophilinae & & & & & & & & \\
\hline Coralliophila burdigalensis ToURNOUËR, 1874 & & Plate IV/22-23 & 14 & & & & & \\
\hline Coralliophila gracilispira BOETTGER, 1906 & $\mathrm{x}$ & Plate IV/24 & & 2 & & & & \\
\hline Coralliophila sacyi (COSSMANN \& PEYROT, 1924) & & Plate IV/25-26 & 1 & & & & & \\
\hline Coralliophila serraticincta BA UK, 1995 & $\mathrm{x}$ & Plate IV/27-29 & & 2 & & & & \\
\hline Leptoconchus jaegeri BOETTGER, 1906 & $\mathrm{x}$ & Plate IV/30-31 & 2 & & & & & \\
\hline
\end{tabular}

B - Bánd, M - Mecsekpölöske, K - Kisbattyán, H - Hidas, Locality 1, Hh - Hosszúhetény, T - Tekeres, E - Central Paratethyan endemic species.

position is of special interest given that some of the species are unknown or very rare at other Badenian sites in the Pannonian Basin.

\section{Kisbattyán}

The geology and stratigraphy of the Kisbattyán region were treated by StRAUSz (1928) and HÁMOR (1970). The Lower Badenian deposits represent the Pécsszabolcs, the Budafa and the Tekeres formations. The locality studied herein was discovered by SÖVÉR in 2010, it is located 800 m northwest of the village in a ravine $\left(46.23327^{\circ} \mathrm{N}, 18.25653^{\circ} \mathrm{E}\right)$. The deposits and the mollusc fauna are very similar to that of the Mecsekpölöske locality. The excavation contains alternating beds of limestone and dark yellow sandy clay layers. For the present study private collections of NÉMETH and SövÉR were examined. The Muricidae species of the locality are shown on Table I. The muricid fauna shows low diversity but the appearance of Ocinebrina boeckhi and Pterynopsis sp. specimens are noteworthy.

\section{Hidas}

The geology and stratigraphy of the classical Hidas region have been dealt with by numerous papers (for research history see BoHN-HAVAS 1973, and SELMECZI 1987 with additional references). The Badenian deposits represent the Pécsszabolcs, the Budafa, the Hidas and the Szilágy Formations. Middle Miocene gastropod assemblages were described e.g. by CSEPREGHY-MEZNERICS (1950), STRAUSZ (1966), and BoHN-HAVAS (1973); these authors identified only five muricid species from the region.

The gastropod materials examined herein came from artificial trenches in a small ravine in a forest area $350 \mathrm{~m}$ south-east of the village $\left(46.25075^{\circ} \mathrm{N}, 18.50690^{\circ} \mathrm{E}\right)$. Until this paper these localities have never been studied in the literature; the Lower Badenian Locality 1 was discovered by NÉMETH and SövÉr in 2013, while the Middle Badenian Locality 2 was first recognised by NÉMETH in the same year. In Locality 1 shallow marine deposits of $2 \mathrm{~m}$ thickness were exposed, the clayey sand represents the Pécsszabolcs Lime- stone. The deposits are very rich in gastropods. Within the Muricidae Bolinus brandaris torularius, Hexaplex (Trunculariopsis) austriacus and Hadriania mioincrassata are abundant. The muricid species are given in Table I. Most of the species also occur in other small localities in the vicinity or can be collected on the ploughed land at the eastern side of the village. The appearance of $B$. brandaris torularius deserves special mention as the species has never been recorded in the Central Paratethys. The size of the T. labiatus shells in this assemblage is slightly larger than at other Pannonian Basin sites. Locality 2 is a small trench approx. $80 \mathrm{~m}$ south of Locality 1 . Clayey sand of $90 \mathrm{~cm}$ thickness was exposed between thin lignite layers; the brackish water deposits represent the Middle Badenian Hidas Brown Coal Formation. The gastropod fauna shows low diversity with the mass occurrences of Vitta tuberculata (SCHRÉTER), Granulolabium nodosoplicatum (HöRNES), Gibborissoia varicosa (BASTEROT), Tritia schoenni (HOERNES \& AUINGER) and Ocinebrina confluens (EICHWALD). Alvania sp., Rissoina sp., Terebralia lignitarium (EICHWALD) and Cyllenina ancillariaeformis (GRATELOUP) appear sporadically. Similar mollusc assemblages without $O$. confluens were earlier recorded from the Hidas area by FöLDI (1966).

\section{Hosszúhetény}

The geology and stratigraphy of the Hosszúhetény region were treated by STRAUSz (1950), SOMOS \& KóKAY (1960), and HÁMOR (1970). The Lower Badenian deposits represent the Pécsszabolcs, the Budafa and the Hidas formations. From the vicinity only one muricid species was recorded by STRAUSZ (1950). The locality studied herein is located $600 \mathrm{~m}$ south of the village $\left(46.13676^{\circ} \mathrm{N}, 18.35458^{\circ}\right.$ E). Lower Badenian clayey sand of $2.5 \mathrm{~m}$ thickness was excavated by artificial trenches, the deposit represents the Pécsszabolcs Fm. The layers are rich in mollusc shell remains and fragments of colonial corals. For the present study the respective private collections of NÉMETH and SövÉR were examined.

The muricid fauna (Table I) is unique in the Pannonian 
Basin. Representatives of the subfamily Ocenebrinae predominate with an abundance of Ocenebra vindobonensis vindobonensis and Vitularia linguabovis. The latter species shows a similar frequent occurrence in the Muricidae fauna of Bánd, but in that fauna $O$. vindobonensis is replaced by the closely allied Ocinebrina kojumdgievae. The specimens of Jaton sowerbyi in the Hosszúhetény assemblage are characterized by moderate morphological variability in height of the spire.

\section{Tekeres}

The geology and stratigraphy of the Orfü-Tekeres region were dealt with by CHIKÁN (1991) and BÁLDI et al. (2002). The Lower Badenian deposits represent the Pécsszabolcs Member and the Tekeres Formation. The locality studied herein is located $100 \mathrm{~m}$ east of the Herman Ottó Lake in the forest $\left(46.17449^{\circ} \mathrm{N}, 18.13063^{\circ} \mathrm{E}\right)$. It was discovered by NÉMETH in 2010, and described first by BosNAKOFF (2013). Clayey sand of $180 \mathrm{~cm}$ thickness was excavated by artificial trenches, the deposit belongs to the Pécsszabolcs Member. The macrofauna is very rich in Early Badenian invertebrate and vertebrate fossils. Two collections were examined: the mollusc assemblage collected by the staff of the HNHM, and the private collection of NÉMETH.

The Muricidae is characterised by a very low diversity with only five species (Table I). The material is of special interest due to the occurrence of the subfamily Typhinae. A single specimen of Typhis (Hirtotyphis) horridus and the abundance of Siphonochelus fistulosus are noted, both species being very rare in other Badenian sites of Hungary. In addition, Pteropurpura friedbergi is reported for the first time in Hungary. It is known only in this assemblage but its occurrence is frequent. Similar gastropod faunal compositions with the co-occurrence of $T$. (H.) horridus, S. fistulosus, P. friedbergi and the rare cancellariid Perplicaria mioquadrata (SACCO) (recorded herein at Tekeres) are known only in the Făget Basin (SW Romania) and the Lom Basin (Vidin-Pleven Region, Bulgarian part of the South Carpathian Foredeep, KoJUmDGIEVA 1960).

\section{Systematic Palaeontology}

Clade Neogastropoda WENZ, 1938

Superfamily Muricoidea RAFINESQUE, 1815

Family Muricidae RAFINESQUE, 1815

Subfamily Muricinae RAFINESQUE, 1815

Genus Bolinus Pusch, 1837

\section{Bolinus brandaris torularius (LAMARCK, 1822)}

(Plate I, figs 1-3)

1822 Murex torularius — LAMARCK, p. 576.

2013 Bolinus brandaris torularius (LAMARCK) — LANDAU et al., p. 144, pl. 21, fig. 1 (cum syn.)

2018 Murex (Bolinus) subtorularius HöRNES \& AUINGER JANEČEK, p. 59, pl. 6, fig. 3.
2019 Bolinus brandaris torularius (LAMARCK) - LANDAU et al., p. 4, pl. 1, figs 1-3 (cum syn.)

Remarks: The species is distinguishable from B. subtorularius (HÖRNES \& AUINGER) - which is common in the Early Badenian of the Pannonian Basin (KovÁcs et al. 2018) - by subquadrangulate last whorl, two rows of welldeveloped spines on the last whorl, and spiny siphonal canal. The specimen illustrated by JANEČEK (2018) as $M$. (B.) subtorularius actually represents $B$. brandaris torularius, it came from an Early Badenian mollusc assemblage of Lomnička (Czechia, Moravian part of the Carpathian Foredeep). The two records confirm a wide geographical range of the species in the Central Paratethys.

Distribution: Middle Miocene-Pleistocene. Middle Miocene: NE Atlantic (France), Central Paratethys (Czechia; Hungary: this paper), Proto-Mediterranean Sea (Turkey).

Subfamily Aspellinae KeEN, 1971

Genus Aspella MÖRCH, 1877

\section{Aspella subanceps (D'ORBIGNY, 1852)}

(Plate I, figs 19-20)

1852 Ranella subanceps - D'ORBIGNY, p. 77.

2007 Aspella subanceps (D’ORBIGNY) — LANDAU et al., p. 21, pl. 6, fig. 9 (cum syn.)

2011 Aspella subanceps (D'ORBIGNY) - MERLE et al., p. 206, textfig. 71/F, pl. 157, figs $1-3$.

2018 Aspella subanceps (D'ORBIGNY) — KovÁCs et al., p. 116, fig. 4/AC.

Remarks: Two Aspella species are known in the early Badenian Central Paratethys: A. subanceps (D'ORBIGNY), and A. emmae (BoetTGER). A. emmae (Plate I/17-18) which is known in the Făget Basin (Romania), Korytnica Basin (Poland) and the N Pannonian Basin (North Hungarian Mountains) - differs from A. subanceps by paucispiral protoconch and smooth shell surface. A. subanceps is very rare in the Pannonian Basin: beside Mecsekpölöske where it is abundant, only one specimen was recorded in the Early Badenian gastropod assemblage of Letkés.

Distribution: Early-Middle Miocene. Middle Miocene: NE Atlantic (France), Central Paratethys (Austria, Hungary, Poland, Romania).

Genus Dermomurex MonTERosato, 1890

Subgenus Dermomurex (Dermomurex)

Dermomurex (Dermomurex) scalaroides (BLAINVILLE, 1829) (Plate I, figs 23-24)

1829 Murex scalaroides - BlAINVILLE, p. 131, pl. 5A, figs 5-6. non 1960 Aspella (Aspella) scalaroides (BlAINVILLE) - KoJUMDGIEVA, p. 148, pl. 40, fig. 7 [= Dermomurex (Trialatella) jani (DODERLEIN, 1862)]

2007 Dermomurex (Dermomurex) scalaroides (BLAINVILLE) LANDAU et al., p. 22, pl. 6, fig. 1 (cum syn.)

2016 Dermomurex (Dermomurex) scalaroides (BLAINVILLE) Ceulemans et al., p. 38, pl. 1, fig. 5. 
Remarks: The species is recorded herein for the first time in Hungary. It differs from $D$. (D.) distinctus (CRISTOFORI \& JAN) (Plate I/21-22) - which is common in the Early Badenian Central Paratethys - in morphology by slender shell and weakly developed spiral sculpture. It also differs from the trivaricate $D$. (Trialatella) jani (DODERLEIN) by numerous varices on the last whorl (KovÁCS et al. 2018).

Distribution: Middle Miocene - Recent. Middle Miocene: NE Atlantic (France), Proto-Mediterranean Sea (Italy), Central Paratethys (Hungary: this paper).

\section{Dermomurex (Dermomurex) sp.}

(Plate I, figs 25-26)

Remarks: The specimen from the muricid assemblage of Mecsekpölöske lacks the protoconch, possesses five rounded teleoconch whorls, ovate aperture with dentate outer lip, weakly developed spiral sculpture of flat, narrow P1, P2, P4 primary cords, slightly stronger $\mathrm{P} 3$ and $\mathrm{P} 5$ primary cords, and four varices on the last whorl. Its morphology differs from that of the common $D$. (D.) distinctus by less developed spiral sculpture, from $D$. (T.) jani by the presence of more varices, and from $D$. (D.) scalaroides by slender shell with higher spire. The most closely allied form in size and overall morphology is the $D$. (D.) cf. tenellus (MAYER) illustrated by MERLE et al. (2011, pl. 165/10) from the Early Miocene of the Aquitaine Basin. However, the specific beaded spiral ornamentation cannot be observed on the specimen figured herein.

Uncertain subfamily (see HOUART 2018 with additional references) Genus Pterynotus SwaInson, 1833

Subgenus Pterynotus (Pterynotus)

Pterynotus (Pterynotus) pseuderinaceus (BOETTGER, 1902) (Plate I, figs 27-28)

1902 Murex (Pteronotus) pseuderinaceus - BOETTGER, p. 28. 1934 Murex (Pterynotus) pseuderinaceus BOETTGER - ZILCH, $\mathrm{p}$. 251, pl. 15, fig. 76.

2019 Pterynotus (Pterynotus) pseuderinaceus (BOETTGER) Kovács, p. 117, figs 13-14.

Remarks: The small specimen figured here possesses an eroded protoconch, 4.5 shouldered teleoconch whorls, an ovate aperture, smooth lips within, and a curved, open siphonal canal. The sculpture consists of primary spiral cords (P) (P1-P2 on the spire whorls, $\mathrm{P} 1-\mathrm{P} 4$ on the last whorl), and axial sculpture of four varices on the spire whorls, and three varices on the last whorl. The morphology contributes to the diagnosis of subgenus Pterynotus (Pterynotus) (trivaricate shell with foliaceus varices, lack of anal notch, generally not spiny spiral sculpture, weakly developed denticles on the outer lip, smooth inner lip) (MERLE et al. 2011). However, the characteristic spiral sculpture with numerous fine cords is absent on the available specimens.

$P$. (P.) pseuderinaceus is recorded herein for the first time in Hungary. It is a poorly known species having hitherto been documented only in its type locality, Coşteiu de Sus (Făget Basin, SW Romania). The congeneric $P$. $(P$.) granuliferus (GRATELOUP) differs in larger size and in morphology by less developed spiral cords on the early spire whorls, and rounded varices.

Distribution: Middle Miocene: Central Paratethys (Hungary: this paper, Romania)

Subfamily Muricopsinae RADWIN \& D’ATtILIO, 1971 Genus Murexsul IREDALE, 1915

\section{Murexsul typhioides (MAYER, 1869) (Plate II, figs 12-13)}

1869 Murex typhioides - MAYER, p. 83, pl. 3, fig. 6. 1995 Aspella (Aspella) typhioides (MAYER) - BAŁUK, p. 219, pl 25, fig. 5 (cum syn.)

2018 Murexsul typhioides (MAYER) - KovÁCs et al., p. 120, figs 5/K, L, 6A-C.

Remarks: The taxonomy and morphology of M. typhioides were discussed by KovÁcs et al. (2018). The species was assigned to Aspella by BAŁUK (1995), however, the latter genus differs by bivaricate morphology. M. typhioides is a rare species, and in Hungary it is known only in the Early Badenian gastropod assemblages of Bánd and Letkés.

Distribution: Early - Middle Miocene. Middle Miocene: NE Atlantic (France), Central Paratethys (Hungary, Poland).

Genus Favartia Jousseaume, 1880

Subgenus Favartia (Favartia)

Favartia (Favartia) suboblonga (D'ORBIGNY, 1852) (Plate II, figs 18-19)

1852 Murex suboblongus - D'ORBIGNY, p. 73.

2007 Favartia suboblonga (D'ORBIGNY) - LANDAU et al., p. 46, text-fig. 12, pl. 12, figs 5-8 (cum syn.)

2016 Favartia suboblonga (D'ORBIGNY) - CEULEMANS et al., p. 40, pl. 1, figs 8-9.

2018 Favartia (s.s.) suboblonga (D'ORBIGNY) — KovÁCs et al., p. 121, fig. 5/Q-T (cum syn.).

Remarks: Three Favartia species occur in the Early Badenian of the Central Paratethys: $F$. (F.) absona (CRISTOFORI \& JAN), F. (F.) czjzeki (HOERNES \& AUINGER) [= Murex (Muricidea) collega BoEtTGER, 1906] and F. (F.) suboblonga (D'ORBIGNY). F. suboblonga differs from $F$. absona (Plate II/14-15) in morphology by higher spire and rounded varices, and from F. czjzeki (Plate II, figs 16-17) by broader shell. The species is widespread but generally rare in the Central Paratethys. Its dominance in the muricid fauna of Mecsekpölöske (Table I) with $47 \%$ is unusual compared to other Paratethyan Middle Miocene sites.

Distribution: Early Miocene - Middle Pliocene. Middle Miocene: NE Atlantic (France), Central Paratethys (Austria, Hungary, Poland, Romania, Slovakia). 
Subfamily Ocenebrinae Cossmann, 1903

Genus Ocinebrina JousSEAUME, 1880

Ocinebrina confluens (EICHWALD, 1853)

(Plate II, figs 24-25)

1853 Murex confluens - EICHWALD, p. 192, pl. 8, fig. 11.

1950 Tritonalia (Hadriania) aff. mioincrassata - CSEPREGHY-

MEZNERICS, p. 48, pl. 2, fig. 19.

1968 Murex confluens EICHWALD - ZELINSKAYA et al., p. 185, pl. 44, figs 5-6.

1971-1972 Tritonalia confluens EICHWALD — CSEPREGHY-MEZNERICS, p. 27, pl. 10, fig. 6.

1994 Murex confluens EICHWALD — IONESI \& NICORICI, pl. 3, fig. 7.

2006 Purpura (Tritonalia) confluens (EICHWALD) - BAŁUK, p. 209, pl. 13, figs 1-3 (cum syn.)

non 2010 Murex (Tritonalia) confluens (EICHWALD) — JovANOVIĆ, text-fig. $1.2(=$ ? Murexsul sp.)

Remarks: As this species lacks well-developed varices typical of genus Ocenebra, here it is assigned to Ocinebrina. Only one specimen was recorded by CSEPREGHYMEZNERICs (1950) from the Mecsek Mts (Hidas area). In the newly discovered Middle Badenian Locality 2 at Hidas, O. confluens (represented by more than 1000 specimens) is one of the most abundant species in the gastropod assemblage. The intraspecific variability is not typical of the local confluens material: the specimens are closely allied to the type in size and morphology but slightly differ by open siphonal canal similarly to the example figured by BAŁUK (2006, pl. 13, fig. 1). The specimen presented by JovANOVIĆ (2010, text-fig. 1.2) is characterised by different morphological features, it represents another taxon.

Distribution: Middle Miocene: Central Paratethys (Hungary, Poland, Romania, Ukraine).

\section{Ocinebrina kojumdgievae (BAŁUK, 1995)} (Plate II, figs 27-30)

1966 Tritonalia vindobonensis (HÖRNES) var. - KÓKAY, p. 57, pl. 8, fig. 6.

1995 Purpura (Tritonalia) kojumdgievae nom. n. - BAŁUK, p. 228 , pl. 30 , fig. 8 .

2017 Ocinebrina kojumdgievae (BAŁUK) — VICIÁN et al., p. 60, pl. 3, fig. 3 (cum syn.)

Remarks: The abundance of $O$. kojumdgievae in the gastropod assemblage of Bánd is noteworthy as the species is usually very rare at other Badenian fossiliferous sites. It differs from the similar Ocenebra vindobonensis vindobonensis (HöRNES) in morphology by broad shell, lower spire and rounded varices. The co-occurrence of the latter species and O. kojumdgievae recorded by BAŁUK in the Korytnica Basin (Poland) is not typical of the Pannonian Basin localities. The kojumdgievae material at Bánd is characterised by moderate intraspecific variability in the strength of the spiral sculpture.

Distribution: Middle Miocene: Central Paratethys (Austria, Bulgaria, Hungary, Poland, Romania).
Ocinebrina landaui KovÁcs, 2019

(Plate III, figs 1-2)

2018 Ocinebrina cf. recognita BAŁUK — KovÁCs et al., p. 123, fig. 7/G-H.

2019 Ocinebrina landaui n. sp. — KovÁcs, p. 129, figs 51-55.

Remarks: Ocinebrina landaui appears in the clayey sand layers of Locality 28 of Bánd. The species is similar in size and morphology to $O$. recognita BAŁUK but differs in sculpture by labral tooth and well-developed secondary cords. It is also distinguishable from $O$. grundensis (HoERNES \& AUINGER) on the bases of its higher spire, labral tooth and sharper spiral cords. The species is widely distributed in the Badenian Central Paratethys: it was described at Coşteiu de Sus (Romania), and it is also documented here in the gastropod assemblage of Letkés.

Distribution: Middle-Late Miocene: Middle Miocene: Central Paratethys (Romania, Hungary: this paper), ProtoMediterranean Sea (Turkey).

\section{Ocinebrina bertai $\mathrm{n} . \mathrm{sp}$.} (Figure 2)

urn:1sid:zoobank.org:act:A627F7BE-7A63-42B2-A2623B7E6C2E34AB

Holotype: PAL 2019.246.1., HNHM, Department of Palaeontology and Geology, SL 19 (Figure 2).

Type strata and locality: Middle Miocene (Lower Badenian) yellow sand, Locality 28, Bánd, Hungary.

Derivation of name: In honour of the collector: Tibor BERTA (Veszprém, Hungary).

Material: holotype (HNHM), and two additional specimens in Collection Berta.

Diagnosis: An Ocinebrina species with biconic shell, worn paucispiral protoconch, five shouldered teleoconch whorls, ovate aperture, dentate outer lip, short, open siphonal canal, well-developed primary cords and fine secondary cords, broad, rounded axial ribs.

Description: Biconic shell of medium size, worn paucispiral protoconch. Teleoconch of five shouldered whorls, suture shallow, undulating. Last whorl $79 \%$ of the total length. Aperture ovate, outer lip slightly thickened, six denticles within (D1-6, D3 splitted). Anal notch slightly developed, columellar lip thin and smooth, siphonal canal open, short and straight. Spiral sculpture of strong and rounded primary cords, 11 on the last whorl, and finer secondary cords. Axial sculpture of broad and rounded ribs, seven on the last whorl.

Remarks: Based on general morphology the new species is assigned to Ocinebrina. The genus shows a remarkable variability in the Badenian Central Paratethys but similar forms with broad biconic shell are unknown in the literature. O. crassilabiata (HILBER) differs in larger size, stronger varices, and well-developed denticles, while $O$. grundensis and $O$. landaui possess rounded teleoconch whorls and sealed canal. O. striata (EICHWALD) is a closely allied spe- 


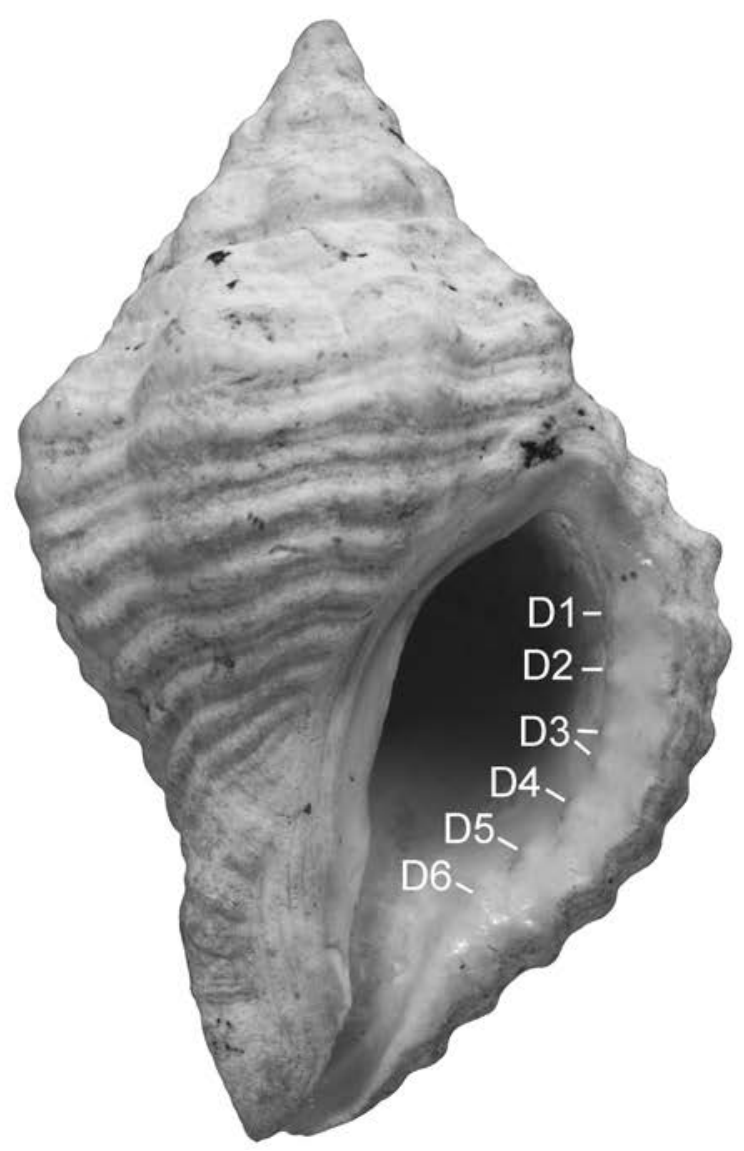

Figure 2. Ocinebrina bertai n. sp. Holotype, SL 19, Scale bar $5 \mathrm{~mm}$

2. ábra. Ocinebrina bertai $n$. sp. Holotípus, hossz: 19, Méretvonal: $5 \mathrm{~mm}$

cies in overall form but characterised by slender shell and higher, usually gradate spire. The Ocinebrina sp. specimens (Plate III/3-4) in the same assemblage are distinguishable by somewhat stronger varices, presence of pseudoumbilicus, and different sculpture with regularly alternating primary and secondary cords.

The material came from a yellow sandy layer of $40 \mathrm{~cm}$ thickness under- and overlaid by clayey sand of marine origin. Ocinebrina sp. and O. bertai n. sp. were associated with abundant specimens of Terebralia lignitarum (EICHWALD), and genera Vitta and Granulolabium; the assemblage is typical of the lagoon paleoenvironment.

\section{Genus Ocenebra GRAY, 1847}

\section{Ocenebra vindobonensis vindobonensis (HÖRNES, 1853)} (Plate III, figs 5-7)

1853 Murex Vindobonensis - HöRNES, p. 252, pl. 25, fig. 17 only. 1943 Murex granuliferus GRATELOUP - STRAUSZ, pl. 3, figs 9, 15 [non Pterynotus granuliferus (GRATELOUP, 1833)]

2016 Ocenebra vindobonensis vindobonensis (HÖRNES) LANDAU et al., p. 224, pl. 1, fig. 4 (cum syn.)

2018 Ocenebra vindobonensis vindobonensis (HöRNES) Kovács et al., p. 123, fig. 7/I, J.

Remarks: This species is not rare in the Early Badenian

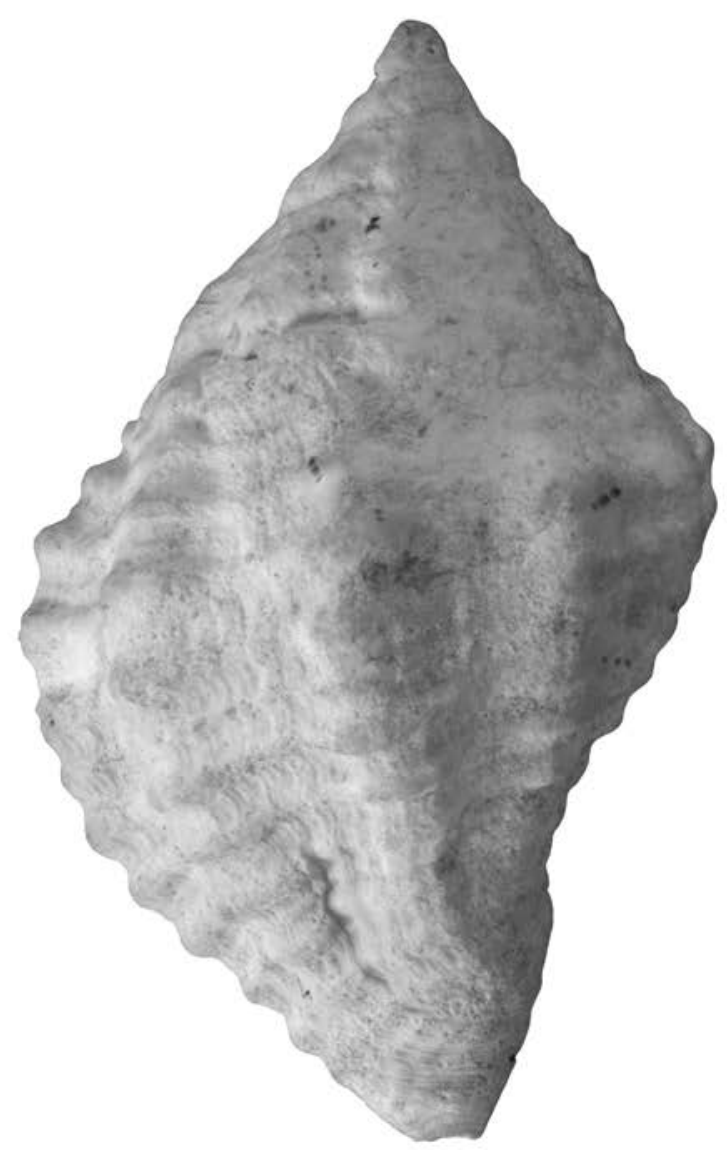

localities of Hungary but extremely abundant in the mollusc assemblage of Hosszúhetény where more than 700 specimens were collected. The specimen identified by STRAUSZ (1943) as M. granuliferus from the neighbouring Pécsvárad area differs in morphology from Pterynotus granuliferus (GRATELOUP), it actually represents $O$. vindobonensis vindobonensis. The studied specimens show moderate intraspecific variability in the development of the sculpture.

Distribution: Early - Middle Miocene. Middle Miocene: Central Paratethys (Austria, Bulgaria, Czechia, Hungary, Poland, Romania, Slovakia), Proto-Mediterranean Sea (France, Turkey).

Genus Pteropurpura Jousseaume, 1880

Pteropurpura friedbergi (COSSMANN \& PEYROT, 1924) (Plate III, figs 15-16)

1924 Murex friedbergi - Cossmann \& PeYrot, 98.

non 1966 Purpura (Tritonalia) delbosiana friedbergi CossMANN \& Peyrot - Symeonidis, p. 279, pl. 57, figs 4-5 [= Pteropurpura delbosiana (GRATELOUP, 1845)]

1968 Murex friedbergi Cossmann \& PEYROT —ZELINSKAYA et al. p. 186 , pl. 44, figs 7-8.

1995 Murex (Tubicauda) friedbergi Cossmann \& PeYrot BAŁUK, p. 212, pl. 22, figs 6-8 (cum syn.)

2016 Murex friedbergi Cossmann \& PEYROT - Wysocka et al., text-fig. 11/C. 
2019 Pteropurpura friedbergi (CoSSMANn \& PEYROT) — KovÁcs, p. 132, figs 59-60.

Remarks: Although the species is widely distributed in the Early Badenian Central Paratethys, it is recorded here for the first time in Hungary. P. friedbergi appears only in the locality of Tekeres in the Hungarian part of the Pannonian Basin and is relatively common in the mollusc assemblage. The specimen illustrated by SYMEONIDIS (1966, pl. 57, figs 4-5) from the Miocene of Crete (Greece) represents $P$. delbosiana (Grateloup), it differs from friedbergi in larger size and in morphology by strong labral varix, and lack of spines on the siphonal canal.

Distribution: Middle Miocene: Central Paratethys (Austria, Bulgaria, Hungary: this paper, Poland, Romania, Ukraine).

Genus Ceratostoma HerRmannsen, 1846

Ceratostoma subaustriacus (STOJASPAL, 1978)

(Plate III, figs 17-18)

1978 Jaton (Ceratostoma) subaustriaca nom. nov. — STOJASPAL, p. 335.

2017 Ceratostoma subaustriacus (STOJASPAL) - Vicián et al., p. 269 , pl. 2, figs 13-14.

2018 Ceratostoma subaustriacus (STOJASPAL) - KovÁcs et al., p. 125 , fig. $7 / \mathrm{P}-\mathrm{S}$.

Remarks: C. subaustriacus is the sole representative of the genus in the Early Badenian assemblages of the Paratethys and is extremely rare. It is only known from three localities: beside the two specimens recorded herein at Bánd, six specimens were documented at Grund (Austria) by HöRNES (1853), and two specimens were described at Letkés by Vicián et al. (2017). The scarcity may be explained by the fact that the Recent Ceratostoma is confined to the temperate zone, while the Mid-Miocene Climate Optimum resulted in a tropical phase in the Early Badenian Central Paratethys.

Distribution: Middle Miocene: Central Paratethys (Austria, Hungary)

Subfamily Trophoninae Cossmann, 1903

Genus Pterynopsis VOKEs, 1972

\section{Pterynopsis sp. \\ (Plate IV, figs 1-2)}

Remarks: The poorly preserved specimen in the Kisbattyán assemblage is characterised by high, conical, gradate spire with 3.5 preserved spire whorls, subangulate shoulder, ovate aperture, foliated and dentate outer lip, smooth columella, straight and open siphonal canal, six varices on the second preserved spire whorl, three varices with P1 spine on the penultimate and last whorls, and two prosocline intervarical axial ribs. These morphological features correspond to the main characteristics of genus Pterynopsis (VOKES 1972). One species, $P$. badensis (NYST, 1881) $[=$ P. tortuosus
(SOWERBY) in the older literature] is known from the Paratethys in Austria, Poland, Romania, Slovakia and Ukraine (BISKUPIČ 2016). However, the specimen figured herein is closer in size and morphology to P. subcontabulata (MILLET, 1854) from the Late Miocene-Pliocene NE Atlantic region (see CEULEMANS et al. 2016, pl. 2, figs 2-4), the two intervarical ribs appear on the specimen illustrated on the website of the Muséum national d'Histoire naturelle (Paris [https://science.mnhn.fr/ institution/mnhn/collection/f/item/a57350]), but the poor state of preservation precludes exact determination. The genus is recorded in Hungary for the first time.

Subfamily Ergalataxinae KURODA, HABE \& OYAMA, 1971

Genus Janssenia LANDAU, HARZHAUSER, İSLAMOĞLU \& SILVA, 2013

Janssenia echinulata (PuSCH, 1837)

(Plate IV, figs 3-10)

1837 Ricinula echinulata - Pusch, p. 140, pl. 11, fig. 27.

1882 Purpura (Stramonita) haemostomoides - HOERNES \& AUINGER, p. 151.

1966 Thais (Stramonita) haemastomoides HOERNES \& AUINGER StRausz, p. 282, text-fig. 129.a, pl. 35, figs 13-15, pl. 64, fig. 1. 1995 Thais (Stramonita) echinulata (PUSCH) - BAŁUK, p. 222, pl. 27, figs 5-6.

2013 Stramonita haemastomoides (HOERNES \& AUINGER) — LANDAU et al., p. 155, pl. 23, fig. 4 (cum syn.)

2013 Janssenia echinulata (PUSCH) - LANDAU et al., p. 157, pl. 23, figs 7-8 (cum syn.)

2018 Janssenia echinulata (PUSCH) - Kovács et al., p. 126, fig. 8/O-Q.

Remarks: This species is extremely abundant in the gastropod assemblage of Bánd. The investigated specimens are characterised by strong intraspecific variability in height of the spire, strength of the spiral rows of tubercles and development of the columellar folds. The large amount of material available made it possible to review the taxonomic validity of Stramonita haemastomoides (HoERNES \& AUINGER). The J. echinulata specimens investigated herein show remarkable differences in the strength of the columellar folds (visible only on $60 \%$ of the material); the very weak development of the folds was also emphasized by LANDAU et al. (2013). The material of HöRNES (1852: 167) was quite small, so it is plausible that the unfolded type of haemastomoides (HöRNES, 1852, pl. 13, fig. 18, designated by HOERNES \& AUINGER 1882: 151) - that possesses an identical morphology with echinulata but folds - in fact represents echinulata. According to LANDAU et al. (2013: 155) all Paratethyan haemastomoides that are recorded in the literature represent J. echinulata. However, only four haemastomoides specimens were listed by the authors from Turkey, and the illustrated specimen (1.c., pl. 23, fig. 4) seems to fit within the variability of J. echinulata. Consequently, it is the arrangement of BAtUK (1995) which is accepted herein, and haemastomoides is regarded as the junior synonym of echinulata.

From a palaeoecological point of view J. echinulata may be compared to the Pliocene-Recent Stramonita haemastoma 
(LINNAEUS) as they are closely allied in size and morphology. The latter species occurs in both tropical and warm temperate water areas, and is typical of rocky littoral habitats where it can occur with a density of hundreds of specimens $/ \mathrm{m}^{2}$ (RILOV et al. 2001). S. haemastoma is a predator of bivalves (ostreoids, mytiloids), gastropods (limpets, vermetids) and cirripedes. It seems plausible that J. echinulata occupied the same habitat in the Badenian sea. The remains of possible prey (bivalves and vermetids) are common in the fossil assemblage of Bánd (e.g. the Vermetus material is over-represented compared to other Badenian localities).

Distribution: Middle Miocene: Central Paratethys (Austria, Bosnia, Bulgaria, Hungary, Poland, Romania, Slovakia, Slovenia), Proto-Mediterranean Sea (Turkey).

Genus Phyllocoma TAPPARone CANEFri, 1880

Phyllocoma michelottii (BELLARDI, 1873)

(Plate IV. figs 19-21)

1873 Ranella michelottii-BELLARDI, p. 275, pl. 15, fig. 22.

2001 Phyllocoma michelottii (BELLARDI) - LOZOUET et al., p. 59, pl. 24, fig. 7 (cum syn.)

Remarks: The type of this species from the Middle Miocene of the Torino Hills (Italy) is a fragmentary specimen (BELLARDI 1873, pl. 15, fig. 22). The specimen presented here from the Letkés assemblage possesses an anterodorsally depressed shell, two varices per whorl and a well-developed spiral sculpture. It agrees well in size and morphology with the materials presented by LozouET et al. $(1993,2001)$ from the Early Miocene of France. P. michelottii differs from Daphnellopsis tournoueri LOZOUET, LEDON \& LESPORT, 1993 (recorded by Kovács et al. 2018 from Hungary) in higher spire and different sculpture. This extremely rare species is documented for the first time in the Paratethys. (The classification of the genus is discussed in the literature, see VERMEIJ \& CARLSON 2000 and HOUART 2018.)

Distribution: Chattian - Middle Miocene. Middle Miocene: Proto-Mediterranean Sea (Italy), Central Paratethys (Hungary: this paper).

Subfamily Coralliophilinae CHENU, 1859

Genus Coralliophila H. ADAMS \& A. ADAMs, 1853

Coralliophila burdigalensis TOURNOUËR, 1874 (Plate IV, figs 22-23)

1874 Coralliophila burdigalensis - TOURNOUËR, p. 296, pl. 9 , fig. 6. 2001 Coralliophila burdigalensis (TOURNOUËR) — LOZOUET et al., p. 60 , pl. 25, figs 1-10 (cum syn.)

2018 Coralliophila burdigalensis TOURNOUËR - KovÁCs et al., p. 129, fig. 9/F-I.

2019 Coralliophila burdigalensis TOURNOUËR — KOVÁCS, p. 137, figs 71-76.

Remarks: Up until now very little has been known about genus Coralliophila in the Miocene Paratethys. However, the new records (BAŁUK 2006, KovÁCs et al. 2018, this paper) demonstrate a higher diversity and a wider geographical distribution of the genus than was recognized before. $C$. burdigalensis is characterized by a highly variable shell morphology (LOZOUET \& RENARD 1998). The species is widespread in the Central Paratethys, occurring in the Lower Badenian deposits of Bánd and Letkés (Pannonian Basin), and Coşteiu and Lăpugiu (Făget Basin). C. gracilispira BOETTGER differs in morphology by slender shell and higher spire (Plate IV/24); C. sacyi (Cossmann \& PeYrot) has a noticeably different sculpture; $C$. biconica BOETTGER possesses flat spire whorls and numerous axial ribs (ZILCH 1934, pl. 15, fig. 83); C. serraticincta BAŁUK has a broader shell and gradate spire. $C$. burdigalensis is associated mainly with Faviidae colonial corals that are abundant in the clayey sand deposits of Bánd (OOSTERBAAN 1990).

Distribution: Chattian - Middle Miocene. Middle Miocene: Central Paratethys (Hungary, Romania).

\section{Coralliophila sacyi (Cossmann \& PEYrot, 1924)} (Plate IV, figs 25-26)

1924 Purpura (Stramonita) Sacyi nov. sp. - Cossmann \& PeYrot, p. 247, pl. 14, figs 51-52.

1998 Coralliophila sacyi (COSSMANn \& PEYRot) — LOzOUET \& RENARD, p. 175, fig. 3.1-4.

2006 Coralliophila sp. — BAŁUK, p. 210, pl. 13, fig. 9.

Remarks: This rare species is closely allied to C. burdigalensis in size but differs in morphology by shouldered whorls, well-developed sculpture of strong primary and weak secondary cords, and marked, narrow axial ribs. $C$. sacyi is typical of the Early Miocene of France, but sporadically occurs in the Middle Miocene of the Central Paratethys as well. The species is a new record in Hungary.

Distribution: Chattian - Middle Miocene. Middle Miocene: Central Paratethys (Hungary: this paper, Poland).

Coralliophila serraticincta BAŁUK, 1995 (Plate IV, figs 27-29)

1995 Coralliophila (Coralliophila) serraticincta-BAŁUK, p. 231, pl. 27 , fig. 10 .

Remarks: The specimens presented herein correspond to the holotype in morphology. The species is distinguishable from the similar $C$. burdigalensis and $C$. gracilispira by biconic shell, lower spire, subangulate whorls and narrower aperture. $C$. biconica differs by flat spire whorls and finer spiral cords. $C$. serraticincta is recorded for the first time in the Pannonian Basin.

Distribution: Middle Miocene: Central Paratethys (Poland, Hungary: this paper).

Genus Leptoconchus RüPPELL, 1834

Leptoconchus jaegeri BOETTGER, 1906 (Plate IV, figs 30-31)

1906 Leptoconchus jaegeri ROLLE - BOETTGER, p. 36. 1934 Magilus jaegeri BOETTGER — ZILCH, p. 252, pl. 15, figs 85-86. 2018 Leptoconchus jaegeri BOETTGER — KovÁcs et al., p. 130, fig. 9/P-V. 
Remarks: Leptoconchus is a very rare genus in the Early Badenian assemblages of the Central Paratethys, and $L$. jaegeri is the only species that has hitherto been known from the Făget Basin (Romania) and Letkés (Pannonian Basin). The specimen figured herein from Bánd slightly differs from the holotype with its sculptured early whorls; it is quite similar to the Letkés material (Kovács et al. 2018, fig. 9/V).

Distribution: Middle Miocene: Central Paratethys (Hungary, Romania).

\section{Conclusions}

In the present paper six newly collected Early Badenian and one Middle Badenian Muricidae assemblages are examined. 38 species are documented from Bánd (Herend Basin) (KóKAY 1966, this paper); the material represents a moderately diverse muricid assemblage that is typical of the Central Paratethys. Similar alpha diversity was recorded in the Korytnica Basin (Poland, BAŁUK 1995, 2006), in the Lom Basin (NW Bulgaria, KoJUMDGIEVA 1960, NIKOLOV 1994), and in the Vienna Basin (e.g. Gainfarn, Bad Vöslau, Steinebrunn, Austria, HoERnES \& AUINGER 1879-1891). A higher diversity (more than 50 species) is known only in two regions (Făget Basin, Romania, KovÁcs 2019; Letkés, N Pannonian Basin, KovÁcs et al. 2018). Noteworthy features in the fauna include (i) the dominance of Janssenia echinulata (Pusch), (ii) the abundance of Favartia (Pygmaepterys) transsylvanica (HOERNES \& AUINGER), Ocinebrina kojumdgievae (BAŁUK) and Morula (s.s.) bellardii (HOERNES \& AUINGER), and (iii) the appearances of the rare Ceratostoma subaustriacus (STOJASPAL) and Coralliophila sacyi (COSSMANN \& PEYROT). 12 species are endemic in the Paratethys (Table I), the endemic ratio is $31 \%$ in the Bánd assemblage. A similar endemicity was observed in the assemblages of Letkés (28\%) and the Făget Basin (approx. $30 \%$ ). From Letkés a new Paratethyan record, Phyllocoma michelottii (BELLARDI) is presented.

Until now not much has been known about the muricids of the Mecsek region; in fact, only six species were described earlier. Based on newly collected materials 31 species are recorded herein, six of them are new records in
Hungary: Bolinus brandaris torularius (LAMARCK), Pterynotus pseuderinaceus (BOETTGER), Ocinebrina landaui Kovács, Pteropurpura friedbergi (COSSMANn \& PEYROT), Dermomurex scalaroides (BLAINVILLE), and Coralliophila serraticincta BAŁUK. Genus Pterynopsis is also recorded for the first time in Hungary. The muricid faunas of the Mecsek Mts are generally characterised by low diversity. Some species are known only in this region in Hungary, others such as Murexsul sandbergeri (HöRNES), Favartia (s.s.) suboblonga (D'ORBIGNY), and Ocenebra vindobonensis vindobonensis (HÖRNES) - are present in an unusual abundance. This paper also documents the extended geographical range of numerous rare species. Five species represent Paratethyan taxa, the endemic ratio is $16 \%$ in the Mecsek assemblage.

The respective occurrences of more than 80 muricid species in the Early Badenian Pannonian Basin System is confirmed by (i) a taxonomic review of the previous literature - especially the monograph of the Miocene gastropods of Hungary (STRAUSZ 1966), (ii) revisions of museum collections (KovÁcs 2019), and (iii) analyses of newly collected mollusc assemblages (KovÁcs et al. 2018; this paper).

\section{Acknowledgements}

I am very grateful to Attila Ősı (Eötvös University, Budapest), Olga PIROs (MGSH, Budapest), Mauro BRUNETTI (Italy), Roland HouART (Belgium), Didier MERLE (France) and Mikhail Rogov (Russia) for their professional help. Radoslav BISKUPIČ (Slovakia) completed the Badenian geographical range of the Muricidae in Slovakian localities of the Vienna Basin. Critical comments of László BuJTOR (University of Pécs), Alfréd DUlai (HNHM, Budapest), Barbara STUDENCKA (Polish Academy of Sciences, Warsaw) and István SzENTE (Eötvös University, Budapest) helped to improve the manuscript. Private fossil collectors: Tibor BerTa, László NÁDAI, Tamás NÉMETH, László Sövér and Zoltán Vicián (Hungary) kindly offered their gastropod materials for study. Domonkos VERESTói-KovÁcs (Budapest) contributed in a most valuable way with work of illustration.

\section{References — Irodalom}

BÁLDI, K., BENKOVICS, L. \& SzTANó, O. 2002: Badenian (Middle Miocene) basin development in SW Hungary: subsidence history based on quantitative paleobathymetry of foraminifera. - International Journal of Earth Sciences (Geologische Rundschau) 91, 490-504. https://doi.org/10.1007/s005310100226

BAŁUK, W. 1995: Middle Miocene (Badenian) gastropods from Korytnica, Poland Part II. — Acta Geologica Polonica 45/3-4, 153-255.

BAŁUK, W. 2006: Middle Miocene (Badenian) gastropods from Korytnica, Poland Part V, Addenda et Corrigenda ad Prosobranchia. Acta Geologica Polonica 56/2, 177-220.

BELLARDI, L. 1873: I molluschi dei terreni terziarii del Piemonte e della Liguria, 1. Cephalopoda, Pteropoda, Heteropoda, Gasteropoda (Muricidae et Tritonidae). - Memorie della Reale Accademia delle Scienze di Torino 27, 33-294.

BERTA, T. \& NÉMETH, T. 2004: Study of the fossil fauna of Bánd (Veszprém County), 200 m SE of the church. — Bakony-kutatási jelentés, Bakonyi Természettudományi Múzeum, Zirc, pp. 11 [in Hungarian]. 
BISKUPIČ, R. 2016: The gastropod Pterynopsis badensis (NYST, 1881) (Neogastropoda: Muricidae: Trophoninae) from the Late Badenian of Studienka Formation of the Vienna Basin (Western Carpathians, Slovakia): A new knowledge and overview. — Mente et Malleo 1/1,39.

BLAINVILLE, H.M.D. de 1828-1830: Malacozoaires ou animaux mollusques. — In: Faune Française. 1-80 (1828), 81-240 (1829), 241320 (1830), Levrault, Paris.

BoetTGeR, O. 1902-1906: Zur Kenntnis der Fauna der mittelmiocänen Schichten von Kostej im Krassó-Szörényer Komitat. Verhandlungen und Mitteilungen des siebenbürgischen Vereins für Naturwissenschaften zu Hermannstadt 51(1902), 1-200, 54(1906), 101-244.

BoHn-Havas, M. 1973: Tortonische Molluskenfauna des Östlichen Mecsek-Gebirges. — Jahrbuch der Ungarischen Geologischen Anstalt 53/4, 951-1161.

BosnaKofF, M. 2013: Badeni otholitok egy tekeresi feltárásból [Badenian otholits from an excavation of Tekeres]. — In: 16. Magyar Öslénytani Vándorgyúlés. Program, elôadáskivonatok, kirándulásvezetô, 12, MÁFI, Orfü (in Hungarian).

Ceulemans, L., Van Dingenen, F., Merle, D. \& Landau, B. 2016: The lower Pliocene gastropods of Le Pigeon Blanc (Loire-Atlantique, northwest France). Part 3 - Muricidae. — Vita Malacologica 15, 35-55.

CHIKÁN, G. 1991: Die Känozoischen Ablagerungen des westlichen Mecsekgebirges. — Jahrbuch der Ungarischen Geologischen Anstalt 72, 1-281.

Cossmann, M. \& Peyrot, A. 1924: Conchologie néogénique de l'Aquitaine. - Actes de la Société Linnéenne de Bordeaux 75, 71-318.

CSEPREGHY-MEZNERICS, I. 1950: Die Tortonische fauna von Hidas (kom. Baranya, Ungarn). — Jahrbuch der Ungarischen Geologischen Anstalt 39/2, 1-115.

CSEPREGHY-MeZneRICS, I. 1956: Die Molluskenfauna von Szob und Letkés. — Jahrbuch der Ungarischen Geologischen Anstalt 45/2, $363-477$.

CSEPREGHY-MEZNERICS, I. 1971-1972: La faune Tortonienne-Inférieure des gisements tufiques de la Montagne de Bükk: Gastropodes II. - Egri Múzeum Évkönyve, 26-36.

Dudko, A., Bence, G. \& Selmeczi, I. 1992: The tectonic origin of Miocene basins on the south-western edge of the Transdanubian Central Range. - A MÁFI Jelentése az 1990. évról, 107-124, (in Hungarian with English abstract).

DulaI, A. 2005: Badenian (Middle Miocene) Polyplacophora from the Central Paratethys (Bánd and Devecser, Bakony Mountains, Hungary). - Fragmenta Palaeontologica Hungarica 23, 29-49.

DulaI, A. 2007: Badenian (Middle Miocene) micromorphic brachiopods from Bánd and Devecser (Bakony Mountains, Hungary). Fragmenta Palaeontologica Hungarica 24-25, 1-13.

Eichwald, E. 1853: Lethaea Rossica ou Paléontologie de la Russie. - Schweizerbart, Stuttgart, 533 p.

FEHSE, D. \& ViCIÁN, Z. 2004: A new Zonarina (Mollusca: Gastropoda: Cypraeidae) from the middle Miocene (Badenian) of Hungary. Földtani Közlöny 134/2, 201-208.

FöLDI M. 1966: A hidasi terület földtani felépítése. — A MÁFI évi jelentése az 1964. évról, 93-111.

HAAS, J. (ed.) 2012: Geology of Hungary. — Springer, pp. 244. https://doi.org/10.1007/978-3-642-21910-8

HÁmOR, G. 1970: Das Miozän des östlichen MecsekGebirges. — Jahrbuch der Ungarischen Geologischen Anstalt 53/1, 1-483.

HARZHAUSER, M. 2002: Marine und brachyhaline Gastropoden aus dem Karpatium des Korneuburger Beckens und der Kreuzstettner Bucht (Österreich, Untermiozän). — Beiträge zur Paläontologie 27, 61-159.

HARZHAUSER, M. \& LANDAU, B. 2016: A revision of the Neogene Conidae and Conorbidae (Gastropoda) of the Paratethys Sea. —Zootaxa 4210/1, 1-178.

Harzhauser, M., Mandic, O. \& Zuschin, M. 2003: Changes in Paratethyan marine molluscs at the Early/Middle Miocene transition: diversity, palaeogeography and palaeoclimate. - Acta Geologica Polonica 53/4, 323-339.

Harzhauser, M., Landau, B. \& Breitenberger, A. 2017: The false limpet Siphonaria in the circum-Tethyan Miocene with emphasis on its occurrence in the Paratethys Sea. - Annalen des Naturhistorischen Museums in Wien, Serie A 119, 115-130.

HoERnES, R. \& AUINGER, M. 1879-1891: Die Gasteropoden der Meeres-Ablagerungen der ersten und zweiten Miocänen MediterranStufe in der Österreichisch-Ungarischen Monarchie. - Abhandlungen der k.k. geologischen Reichsanstalt 12, 1-382, 50 pls. Published in parts: 1-52, pls 1-6 (1879), 53-112, pls 7-12 (1880), 113-153, pls 13-16 (1882), 154-192, pls 17-22 (1884), 193-232, pls 23-28 (1885), 233-282, pls 29-36 (1890), 283-330, pls 37-42 (1891), 331-382, pls 43-50 (1891).

HOUART, R. 2018: Historique et classification des espèces actuelles de Muricidae (Neogastropoda, Muricoidea). — Novapex 19/2, 37-66.

HöRNES, M. 1851-1870: Die fossilen Mollusken des Tertiär-Beckens von Wien. - Abhandlungen der Kaiserlich-Königlichen Geologischen Reichsanstalt, 3-4, 1-42, pl. 1-5 (1851), 43-208, pl. 6-20 (1852), 209-296, pl. 21-32 (1853), 297-382, pl. 33-40 (1854), 383-460, pl. 41-45 (1855), 461-736, pl. 46-52 (1856) (3); 1-479, pls 1-85 (1870) (4).

IONESI, B. \& NICOROCI, E. 1994: Contributions à l'études des mollusques badéniens de Crivineni-Pătărlagele. — In: NiCORICI, E. (ed.): The Miocene from the Transylvanian Basin, Romania, 55-64, Editura Carpatica, Cluj-Napoca.

JANEČEK, T. 2018: Systematická a paleoekologická analýza kolekce spodnobadenských fosilií z lokality Lomnička uložené ve Vlastivědném muzeu v Olomouci. — Thesis, Palacký University, Olomouc, pp. 100. https://theses.cz/id/wqjayf/DP_Lomnika_ Tom_Janeek.pdf (Download: 11.08.2018).

Jovanović, G. 2010: Badenian Gastropods of Trnjane near Negotin (Eastern Serbia). — Proceedings of the $15^{\text {th }}$ Congress of Geologists of Serbia with international participation, 83-86.

Kojumdgieva, E. 1960: Le Tortonien du type viennois. - In: Kojumdgieva, E. \& Strachimirov, B.: Les fossiles de Bulgarie, VII, Tortonien, 1-246, Academie des Sciences de Bulgarie, Sofia.

KóKAY, J. 1966: Geologische und paläontologische Untersuchung des Braunkohlengebietes von Herend — Márkó (Bakony-Gebirge, Ungarn). - Geologica Hungarica, Series Palaeontologica 36, 1-147. 
KóKAY, J. 2006: Nonmarine mollusc fauna from the Lower and Middle Miocene, Bakony Mts, W Hungary. — Geologica Hungarica, Series Palaeontologica 56, 1-196.

Kovács, Z. 2018a: Description of three new species of Muricidae (Neogastropoda) from the Miocene Paratethys. — Novapex 19/1, 29-35.

Kovács, Z. 2018b: New records of the genus Euthria (Mollusca, Buccinidae) in the Miocene Paratethys. — Földtani Közlöny 148/2, 179_ 182. https://doi.org/10.23928/foldt.kozl.2018.148.2.179

Kovács, Z. 2019: Muricidae (Neogastropoda) assemblages from the Middle Miocene of the Făget Basin (Romania) in the collection of the Hungarian Natural History Museum, Budapest. — Fragmenta Palaeontologica Hungarica 35 (2018), 111-142. https://doi.org/ 10.17111/FragmPalHung.2018.35.111

Kovács, Z. \& Vicián, Z. 2014: Badenian (Middle Miocene) Conoidean (Neogastropoda) fauna from Letkés (N Hungary). — Fragmenta Palaeontologica Hungarica 30, 53-100.

Kovács, Z. \& Vicián, Z. 2018: Middle Miocene Tonnoidea and Ficoidea (Caenogastropoda) assemblages from Letkés (Hungary). — Fragmenta Palaeontologica Hungarica 34, 75-104. https://doi.org/10.17111/FragmPalHung.2017.34.75

Kovács, Z., HirmetZL, T. \& Vicián, Z. 2018: Miocene Muricidae (Neogastropoda) assemblage from Letkés (Hungary). — Bollettino Malacologico 54/2, 110-133.

LAMARCK, J. B. P. A. de M. 1822: Histoire naturelle des animaux sans vertèbres, 7. — Paris (Lamarck), 711 p.

Landau, B. M., Houart, R. \& Silva, C. M. 2007: The Early Pliocene Gastropoda (Mollusca) of Estepona, Southern Spain. Palaeontos 11, 1-87.

Landau, B., Harzhauser, M., İslamoĞLu, Y. \& Silva, C. M. 2013: Systematics and palaeobiogeography of the gastropods of the middle Miocene (Serravallian) Karaman Basin, Turkey. — Cainozoic Research 11-13, 1-584.

Landau, B., Harzhauser, M., BüyÜKmeriç, Y. \& Breitenberger, A: 2016. Additions to the gastropods of the middle Miocene (Serravallian) Karaman Basin, Turkey. — Cainozoic Research 16/2, 221-229.

Landau, B., Merle, D., Ceulemans, L. \& Van Dingenen, F. 2019: The upper Miocene gastropods of northwestern France, 3. Muricidae. - Cainozoic Research 19/1, 3-44.

Lozouet, P. \& RENARD, P. 1998: Les Coralliophilidae, Gastropoda de l'Oligocène et du Miocène inférieur d'Aquitaine (Sud-Ouest de la France): systématique et coraux hôtes. — Geobios 31/2, 171-184. https://doi.org/10.1016/s0016-6995(98)80037-5

Lozouet, P., Ledon, D. \& Lesport, J.-F. 1993: Le genre Lindapterys (Neogastropoda, Muricidae): un exemple de disjonction de distribution en domaine tropical marin. - Geobios 2, 39-50. https://doi.org/10.1016/s0016-6995(06)80210-x

Lozouet, P., Lesport, J.-F. \& RenARD, P. 2001: Révision des Gastropoda (Mollusca) du Stratotype de l'Aquitanien (Miocène inf.): site de Saucats "Lariey”, Gironde, France. - Cossmannia, Hors-série 3, GERMC, 190 p.

MAYER, C. 1869: Descriptions de Coquilles fossiles des terrains tertiaires supérieurs. - Journal de Conchyliologie 17, 82-86.

Merle, D., Garrigues, B. \& Pointier, J.-P. 2011: Fossil and Recent Muricidae of the World. Part Muricinae. —ConchBooks, 648 p.

Nikolov, P. I. 1994: Some molluscs from the Badenian (Middle Miocene) west of Pleven (Central Northern Bulgaria). II. Gastropoda: order Neogastropoda. - Geologica Balcanica 24/4, 45-70.

OosterbaAn, A. 1990: Notes on a collection of Badenian (Middle Miocene) corals from Hungary in the National Museum of Natural History at Leiden (The Netherlands). - Contributions to Tertiary and Quaternary Geology 27/1, 3-15.

ORBIGNY, A. d' 1852: Prodrome de paléontologie stratigraphique universelle des animaux mollusques et rayonnés, faisant suite au cours élémentaire de paléontologie et de géologie stratigraphique, 3. — Masson, Paris, 196 p, index 189 p.

Pusch, G. G. 1836-1837: Polens Paläontologie oder Abbildung und Beschreibung der vorzüglichsten und der noch unbeschriebenen Petrefakten aus den Gebirgsformationen in Polen, Volhynien und den Karpathen. — Schweizerbart, Stuttgart, 1-80, pls 1-10 (1836), 81-218, pls 11-16 (1837).

Rilov, G., Benayahu, Y. \& Gasith, A. 2001: Low abundance and skewed population structure of the whelk Stramonita haemastoma along the Israeli Mediterranean coast. — Marine Ecology Progress Series 218, 189-202. https://doi.org/10.3354/meps218189

Sant, K., Palcu, D., Turco, E., Di Stefano, A., Baldassini, N., Kouwenhoven, T., Kuiper, K. \& Krijgsman, W. 2019: The midLanghian flooding in the eastern Central Paratethys: integrated stratigraphic data from the Transylvanian Basin and SE Carpathian Foredeep. —International Journal of Earth Sciences 108/7, 2209-2232. https://doi.org/10.1007/s00531-019-01757-z

Sebe, K., Csillag, G., Dulai, A., Gasparik, M., Magyar, I., Selmeczi, I., Szabó, M., Sztanó, O. \& Szuromi-Korecz, A. 2015 : Neogene stratigraphy in the Mecsek region. — In: Bartha, R., Kriván, Á., Magyar, I. \& Sebe, K. (eds): Neogene of the Paratethyan Region. $6^{\text {th }}$ Workshop on the Neogene of Central and South-Eastern Europe. An RCMNS Interim Colloquium. Programme, Abstracts, Field Trip Guidebook, Hungarian Geological Society, Budapest, 102-124.

SELmECZI, I. 1987: Mollusc species in the Miocene formations of the Hidas Browncoal Basin (S Hungary) proving connections with the Eastern Paratethys. - Földtani Közlöny 117/1, 71-78 (In Hungarian with English abstract).

SELMECZI, I. 2015: Geological description of the superficial formations of Hungary. Middle Miocene. — In: KerCSMÁr, Zs. (ed.): Surface geology of Hungary. Explanatory notes to the Geological map of Hungary (1:500 000). Geological and Geophysical Institute of Hungary, Budapest, 38-44.

Somos, L. \& KóKAY, J. 1960: Geologische Beobachtungen im Lias und Miozän des Mecsekgebirges. — Földtani Közlöny 90/3, 331-347 (In Hungarian with German summary).

Stojaspal, F. 1978: Muricidae. - In: PApp, A., Cicha, I., Seneš, J. \& Steininger, F.: M4 Badenien. Chronostratigraphie und Neostratotypen 6. 333-340, Veda, Bratislava.

Strausz, L. 1928: Das Mediterran des Mecsekgebirges in Südungarn. — Geologische und Palaeontologische Abhandlungen, N. F. 15/5, 361-418.

Strausz, L. 1943: Über das Mediterran von Pécsvárad, Püspöklak und Várpalota. — Földtani Közlöny 73/1-3, 228 -232.

Strausz, L. 1950: Deux faunes miocénes de la Montagne Mecsek, Hongrie. — Földtani Közlöny 80/7-9, 245-246. 
STRAUSZ, L. 1966: Die miozän-mediterranen Gastropoden Ungarns. — Akadémiai, Budapest, 692 p.

SYMEONIDIS, N. 1966: Das Neogen von Ostkreta. —Annales Géologiques des Pays Helléniques 16, 249-314.

TOURNOUËR, R. 1874: Description de coquilles des faluns. - Journal de Conchyliologie 22, 288-308.

Vicián, Z., KRock, H. \& KováCs, Z. 2017: New gastropod records from the Cenozoic of Hungary. — Földtani Közlöny 147/3, $265-282$. https://doi.org/10.23928/foldt.kozl.2017.147.3.265

VermeiJ, G. J. \& CARLson, S. J. 2000: The muricid gastropod subfamily Rapaninae: phylogeny and ecological history. — Paleobiology 26/1, 19-46.

VOKES, E. 1972: Pterynopsis, new genus of Trophoninae (Gastropoda). - Bulletin de l'Institut Royal des Sciences Naturelles de Belgique. Sciences de la Terre 48/9, 1-7.

Wysocka, A., Radwanski, A., Gorka, M., Babel, M., Radwanska, U. \& Zıotnik, M. 2016: The Middle Miocene of the ForeCarpathian Basin (Poland, Ukraine and Moldova). - Acta Geologica Polonica 66/3, 351-401. doi:10.1515/agp-2016-0017

ZILCH, A. 1934: Zur Fauna des Mittel-Miocans von Kostej (Banat); Typus Bestimmung und Tafeln zu O. Boettger's Bearbeitungen. — Senckenbergiana 16, 193-302.

Zelinskaya, V. A., Kulichenko, V. G., Makarenko, D. E. \& Sorochan, E. A. 1968: Gastropod and scaphopod molluscs of the Paleogene and Miocene of Ukraine. - Paleontologicheskij Spravochnik 2, 1-282 (in Russian).

Manuscript recieved: 25/09/2019

\section{Plate I — I. tábla}

Figs 1-2. Bolinus brandaris torularius (LAMARCK), SL $53(1.2 \times)$, Hidas.

Fig. 3. Bolinus brandaris torularius (LAMARCK), SL 32 (1.5×), Hidas.

Figs 4-5. Bolinus submuticus (GratelouP), SL 29 (1×), Bánd.

Figs 6-7. Hexaplex (Trunculariopsis) austriacus (TOURNOUËR), SL 59 (1×), Bánd.

Figs 8-9. Hexaplex (Trunculariopsis) austriacus (TOURNOUËR), SL 48 (1×), Hidas.

Fig. 10. Chicoreus (Triplex) aquitanicus (GRATELOUP), SL 65 (1×), Hosszúhetény.

Figs 11-12. Chicoreus (Triplex) borni (HöRNES), SL 58 (1×), Bánd.

Figs 13-14. Chicoreus (Triplex) borni (HöRNES), SL 48 (1×), Hosszúhetény.

Figs 15-16. Purpurellus cyclopterus (MILLET), SL 34 (1.3×), Mecsekpölöske.

Figs 17-18. Aspella emmae (BOETTGER), SL 8 (4×), Bánd.

Figs 19-20. Aspella subanceps (D’ORBIGNY), SL 10 (3x), Mecsekpölöske.

Figs 21-22. Dermomurex (Dermomurex) distinctus (CRISTOFORI \& JAN), SL 25 (1.6×), Bánd.

Figs 23-24. Dermomurex (Dermomurex) scalaroides (BLAINVILLE), SL 12 (3×), Kisbattyán.

Figs 25-26. Dermomurex (Dermomurex) sp., SL 10.4 (3x), Mecsekpölöske.

Figs 27-28. Pterynotus (Pterynotus) pseuderinaceus (BOETTGER), SL 8 (6×), Mecsekpölöske.

Fig. 29. Typhinellus labiatus (CRISTOFORI \& JAN), SL 18 (2×), Bánd.

Scale bars/Méretvonalak: 5 mm for Figs 1-16, 21-22, 29; 1 mm for Figs 17-20, $23-28$.

\section{Plate II — II. tábla}

Figs 1-2. Typhinellus labiatus (CRISTOFORI \& JAN), SL 25 (1.6×), Hidas.

Figs 3-4. Siphonochelus fistulosus (BROCCHI), SL 10.5 (3×), Tekeres.

Figs 5-6. Tripterotyphis tripterus (GRATELOUP), SL 9 (3.5×), Bánd.

Figs 7-8. Subpterynotus graniferus (MichelOTTI), SL 56 (1×), Bánd.

Fig. 9. Murexsul sandbergeri (HÖRNES), SL 27 (1.8×), Mecsekpölöske.

Figs 10-11. Murexsul sandbergeri (HöRNES), SL 34 (1.5×), Mecsekpölöske.

Figs 12-13. Murexsul typhioides (MAYER), SL 10 (3.5×), Bánd.

Figs 14-15. Favartia (Favartia) absona (CRISTOFORI \& JAN), SL 12 (3×), Bánd.

Figs 16-17. Favartia (Favartia) czjzeki (HOERNES \& AUINGER), SL 8.5 (4.5×), Bánd.

Figs 18-19. Favartia (Favartia) suboblonga (D’ORBIGNY), SL 15 (3×), Mecsekpölöske.

Figs 20-21. Favartia (Pygmaepterys) transsylvanica (HOERnes \& AUINGER), SL 14.5 (3×), Bánd.

Figs 22-23. Ocinebrina boeckhi (HOERNES \& AUINGER), SL 27 (2×), Kisbattyán.

Figs 24-25. Ocinebrina confluens (EICHWALD), SL 18 (2×), Hidas (Locality 2).

Fig. 26. Ocinebrina dertonensis (BELLARDI), SL 25 (1.6×), Hosszúhetény.

Figs 27-28. Ocinebrina kojumdgievae (BAŁUK), SL 33 (1.6×), Bánd.

Figs 29-30. Ocinebrina kojumdgievae (BAŁUK), SL 36 (1.6×), Bánd.

Scale bars/Méretvonalak: 5 mm for Figs 1-2, 7-11, 22-30; 1 mm for Figs 3-6, 12-21. 


\section{Plate III - III. tábla}

Figs 1-2. Ocinebrina landaui KovÁcs, SL 21 (2×), Bánd.

Figs 3-4. Ocinebrina sp., SL 18 (2×), Bánd.

Fig. 5. Ocenebra vindobonensis vindobonensis (HöRNES), SL 29 (1.5×), Hosszúhetény.

Figs 6-7. Ocenebra vindobonensis vindobonensis (HÖRNES), SL 35 (1.5×), Hosszúhetény.

Figs 8-9. Hadriania mioincrassata (SACCO), SL 35.5 (1.2×), Hidas.

Figs 10-11. Jaton sowerbyi (MicheLOTTI), SL 53 (1.2×), Bánd.

Figs 12-13. Jaton sowerbyi (MicheLOTTI), SL 47 (1.2×), Hosszúhetény.

Fig. 14. Jaton sowerbyi (MichelotTI), SL 38 (1.2×), Hosszúhetény.

Figs 15-16. Pteropurpura friedbergi (COSSMANN \& PEYROT), SL 33 (2x), Tekeres.

Figs 17-18. Ceratostoma subaustriacus (STOJASPAL), SL 81 (1×), Bánd.

Figs 19-20. Vitularia linguabovis (BASTEROT), SL 74 (0.9×), Hosszúhetény.

Scale bars/Méretvonalak: $5 \mathrm{~mm}$

\section{Plate IV. — IV. tábla}

Figs 1-2. Pterynopsis sp., SL 21 (2×), Kisbattyán.

Figs 3-4. Janssenia echinulata (PuSCH), SL 23 (1.3×), Bánd.

Figs 5-6. Janssenia echinulata (PUSCH), SL 32 (1.3×), Bánd.

Fig. 7. Janssenia echinulata (PUSCH), SL 32 (1.3×), Hosszúhetény.

Fig. 8. Janssenia echinulata (PUSCH), SL 53 (1.3×), Bánd.

Figs 9-10. Janssenia echinulata (PUSCH), SL 48 (1.3×), Bánd.

Figs 11-12. Janssenia spinosa (KoJUMDGIEVA), SL 23 (2×), Bánd.

Figs 13-14. Cathymorula exilis (HöRNES), SL 32 (1.3×), Hosszúhetény.

Figs 15-16. Morula (Morula) bellardii (HOERNES \& AUINGER), SL 9 (4×), Bánd.

Figs 17-18. Morula (Habromorula) austriaca (HoERnES \& AUINGER), SL 20 (2×), Bánd.

Figs 19-21. Phyllocoma michelottii (Bellardi), SL 23 (2×), Letkés.

Figs 22-23. Coralliophila burdigalensis TOURNOUËR, SL 9 (4×), Bánd.

Fig. 24. Coralliophila gracilispira BOETTGER, SL 9 (4×), Mecsekpölöske.

Figs 25-26. Coralliophila sacyi (Cossmann \& PeYrot), SL 10.5 (3×), Bánd.

Fig. 27. Coralliophila serraticincta BAŁUK, SL 6 (4.5×), Mecsekpölöske.

Figs 28-29. Coralliophila serraticincta BAŁUK, SL 10.2 (4×), Mecsekpölöske.

Figs 30-31. Leptoconchus jaegeri BOETTGER, SL 14.5 (2.7×), Bánd.

Scale bars/Méretvonalak: 5 mm for Figs 1-14, 19-21, 2 mm for Figs 15-18, 22-31. 


\section{Plate I — I. tábla}

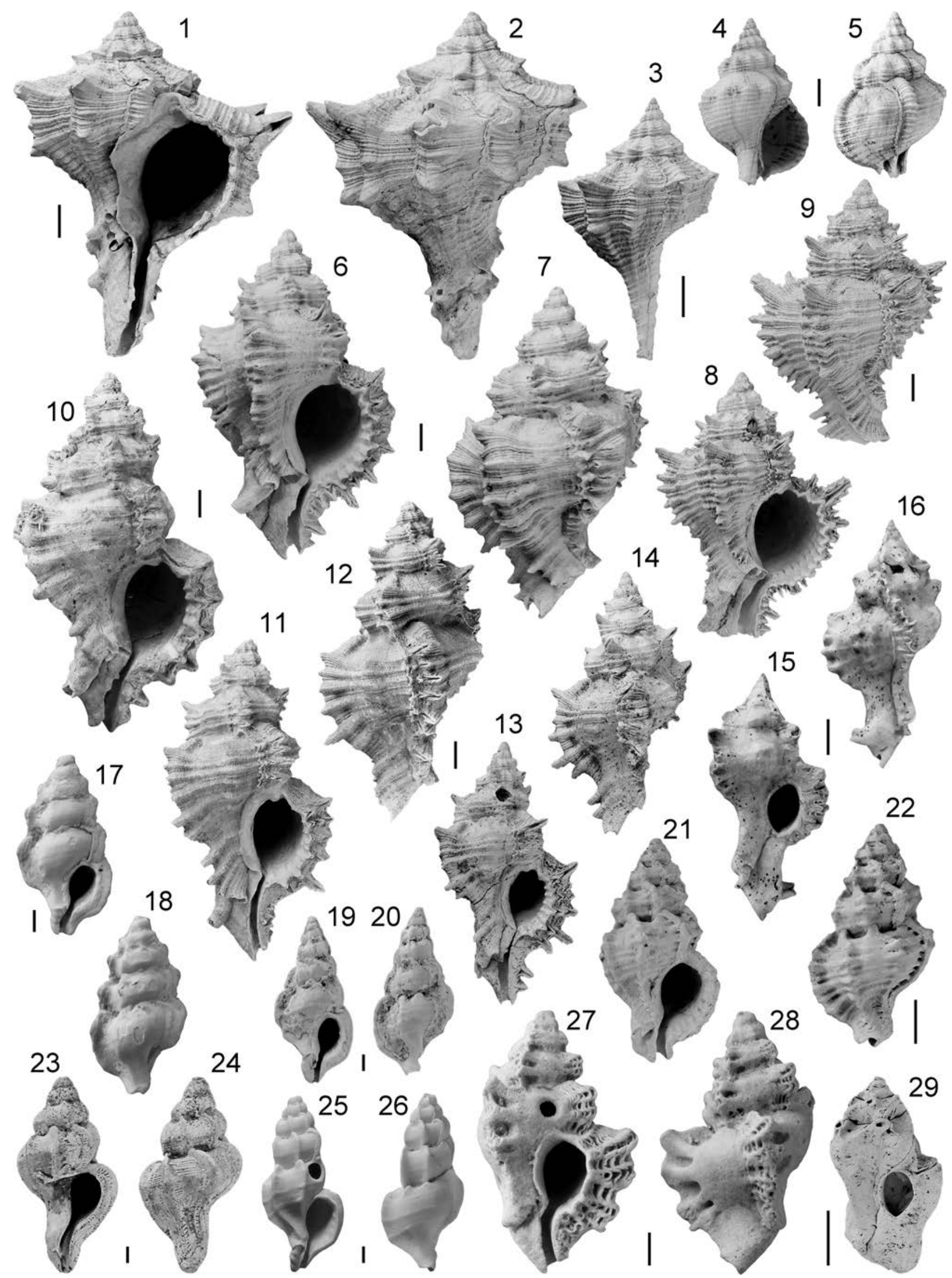




\section{Plate II - II. tábla}

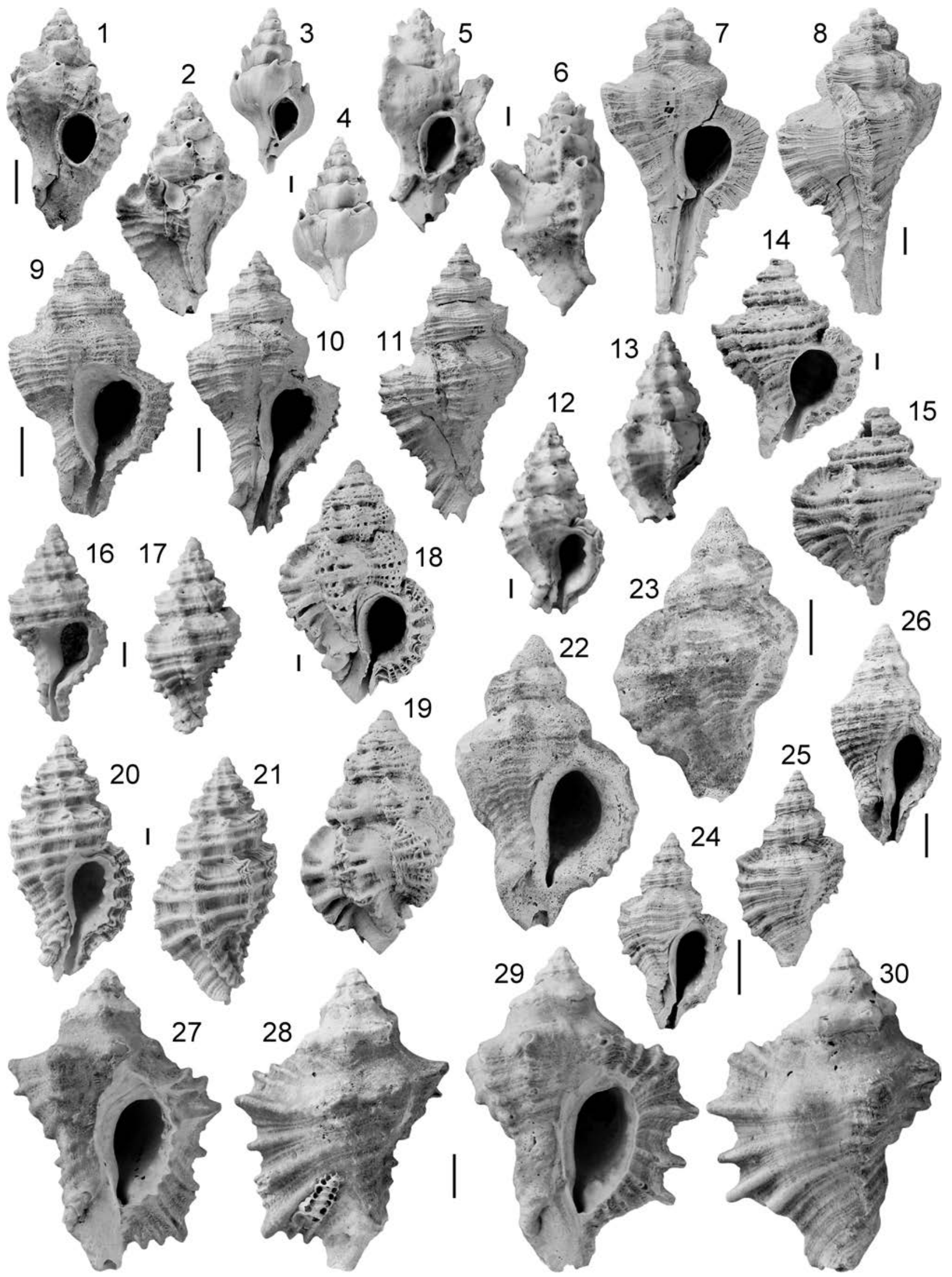




\section{Plate III - III. tábla}

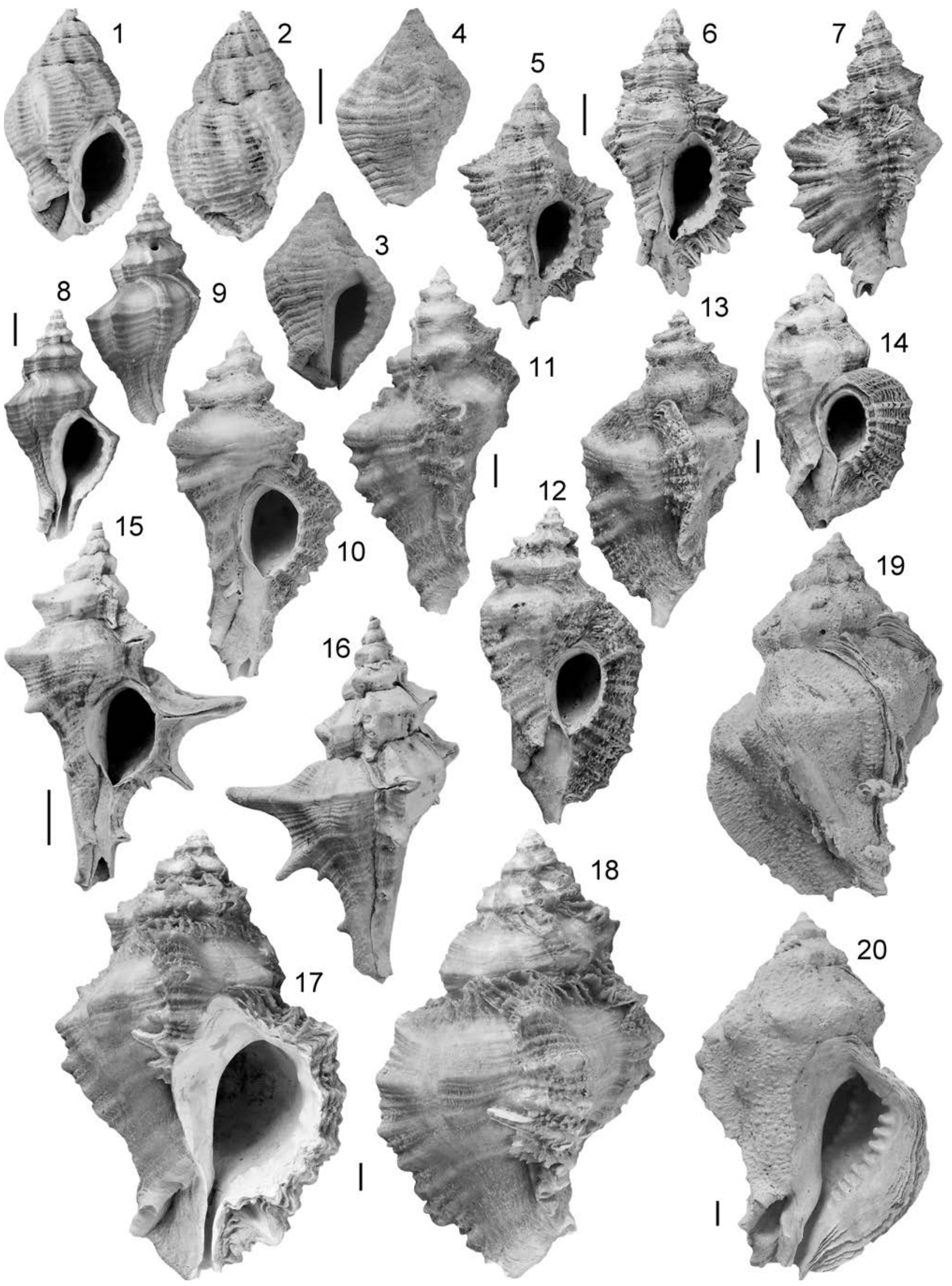


Plate IV - IV. tábla

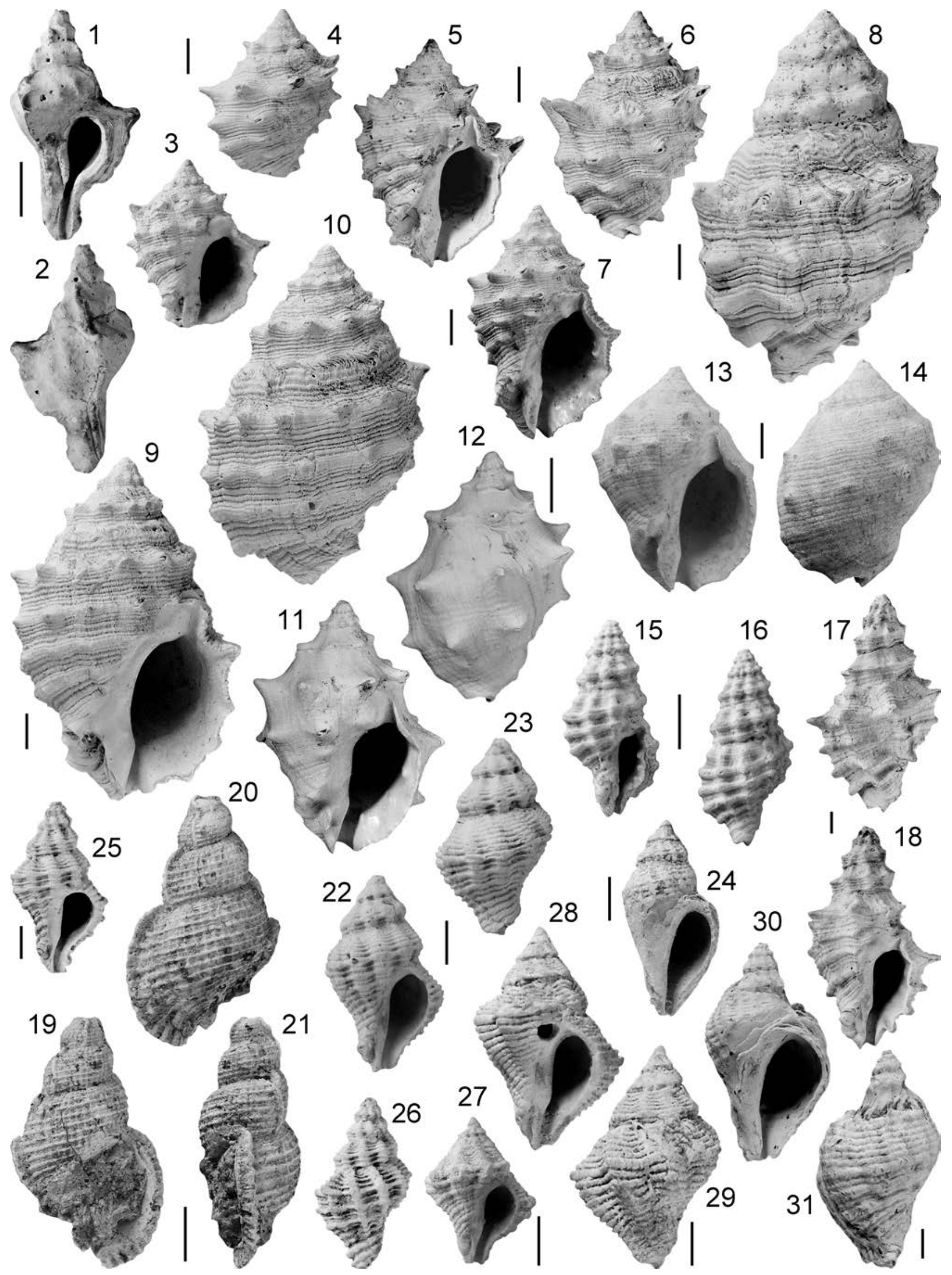

